Article

\title{
The Oxygen Paradigm-Quantitative Impact of High Concentrations of Dissolved Oxygen on Kinetics and Large-Scale Production of Arthrospira platensis
}

\author{
Sabine Franke ${ }^{1,+}{ }^{+}$Juliane Steingröwer ${ }^{1}$, Thomas Walther ${ }^{1}$ and Felix Krujatz ${ }^{1,2, *,+}$ (D) \\ 1 TU Dresden, Institute of Natural Materials Technology, Bergstraße 120, 01069 Dresden, Germany; \\ sabine_franke@web.de (S.F.); juliane.steingroewer@tu-dresden.de (J.S.); \\ thomas_walther@tu-dresden.de (T.W.) \\ 2 biotopa gGmbH-Center for Applied Aquaculture \& Bioeconomy, Bautzner Landstraße 45, \\ 01454 Radeberg, Germany \\ * Correspondence: Felix.Krujatz@tu-dresden.de; Tel.: +49-351-46332420 \\ + The authors contributed equally to this manuscript.
}

check for updates

Citation: Franke, S.; Steingröwer, J.; Walther, T.; Krujatz, F. The Oxygen Paradigm-Quantitative Impact of High Concentrations of Dissolved Oxygen on Kinetics and Large-Scale Production of Arthrospira platensis. ChemEngineering 2022, 6, 14.

https://doi.org/10.3390/ chemengineering6010014

Academic Editor: Eleonora Sforza

Received: 20 December 2021

Accepted: 28 January 2022

Published: 2 February 2022

Publisher's Note: MDPI stays neutral with regard to jurisdictional claims in published maps and institutional affiliations.

Copyright: () 2022 by the authors. Licensee MDPI, Basel, Switzerland. This article is an open access article distributed under the terms and conditions of the Creative Commons Attribution (CC BY) license (https:/ / creativecommons.org/licenses/by/ $4.0 /)$.

\begin{abstract}
The cultivation of Arthrospira platensis in tubular photobioreactors (tPBRs) presents a promising approach for the commercial production of nutraceuticals and food products as it can achieve high productivity and effective process control. In closed photobioreactors, however, high amounts of photosynthetically produced oxygen can accumulate. So far, there has been a wide range of discussion on how dissolved oxygen concentrations (DOCs) affect bioprocess kinetics, and the subject has mainly been assessed empirically. In this study, we used photorespirometry to quantify the impact of DOCs on the growth kinetics and phycocyanin content of the widely cultivated cyanobacterium A. platensis. The photorespirometric routine revealed that the illumination intensity and cell dry weight concentration are important interconnected process parameters behind the impact that DOCs have on the bioprocess kinetics. Unfavorable process conditions such as low biomass concentrations or high illumination intensities yielded significant growth inhibition and reduced the phycocyanin content of $A$. platensis by up to $35 \%$. In order to predict the biomass productivity of the large-scale cultivation of $A$. platensis in tPBRs, a simple process model was extended to include photoautotrophic oxygen production and accumulation in the tPBR to evaluate the performance of two configurations of a $5000 \mathrm{~L}$ tPBR.
\end{abstract}

Keywords: photorespirometry; Arthrospira platensis; tubular photobioreactor; dissolved oxygen; process modeling

\section{Introduction}

Around 3000-4000 metric tons per annum of Arthrospira platensis (also known as Spirulina) biomass is produced commercially worldwide by companies such as Earthrise Nutritionals (Irvine, CA, USA) and the Siam Algae Company (Bangkok, Thailand) [1]. This underlines the rising interest in A. platensis in the food [1,2] and feed [3,4] industry for its high nutritive value, such as a high protein content of $43-65 \%(w / w)$, and a balanced profile of essential amino acids [2]. Besides the food sector, biomass from A. platensis is also commercially valued as a dietary supplement $[1,2,5]$ since an intake of dried A. platensis has been proven to reduce blood cholesterol levels and improve patients' lipid profiles [6,7]. Recent studies have further attributed anti-inflammatory, immunostimulatory, antioxidant, cancer-inhibiting [8,9] and antiviral [10] properties to cyanobacterial biomass and metabolites [11,12] such as phycocyanin (8-13\% $w / w$ of dry biomass [13]) and carotenoids $(0.15-0.2 \% w / w$ of dry biomass [14]). As an example, Zeaxanthin is believed to reduce the risk of age-related macular degeneration $[15,16]$. A. platensis further contains lipids that are of medical interest (6-13\% [17]), such as polyunsaturated $\gamma$-linolenic acid, known 
among other things for its anti-inflammatory properties and beneficial impact on the risk of coronary heart disease $[18,19]$.

Basically, phototrophic microorganisms are cultivated in open or closed photobioreactors. Tubular photobioreactors (tPBRs) are common in industrial cultivation [20], since high volumetric biomass productivity and good process control can be achieved with a reduced risk of contamination compared to open cultivation systems [20,21]. However, a lower gas transfer efficiency in closed tubes is among the disadvantages of tPBR systems, resulting in photoautotrophically produced oxygen accumulation and the formation of oxygen gradients alongside the closed tPBRs [20,22]. Weissman et al. [23] showed that tPBRs can exhibit volumetric rates of oxygen evolution that are up to 25 times higher compared to open pond systems (20 cm depth). As an example, at the maximum photosynthesis rate of Chlorella sp., oxygen accumulation in tPBRs (tube diameter: $1 \mathrm{~cm}$ ) can account for as much as $8-10 \mathrm{mgO}_{2} \mathrm{~L}^{-1} \mathrm{~min}^{-1}$, resulting in an increase in the dissolved oxygen concentration (DOC) of $100 \mathrm{mg} \mathrm{L}^{-1}$ (assuming a tube length of $100 \mathrm{~m}$ ) without any gas exchange [23]. Torzillo et al., observed a DOC rate of $2-3 \mathrm{mgO}^{-1} \mathrm{~min}^{-1}$ for outdoor cultivations of $A$. platensis (tPBR, tube diameter: $5 \mathrm{~cm}$ ), resulting in a maximum DOC of $70-80 \mathrm{mgO} \mathrm{L}^{-1}[24,25]$. This oxygen accumulation capacity indicates the high risk of the formation of spatial DOC gradients along the tube axis and the need to manage the gas-liquid mass transfer in tPBRs [25,26]. Kazbar et al. [26] compared the mass transfer parameter $k_{L} a$ and the maximum DOC attainable with several PBR systems and concluded that oxygen accumulation may result in the inhibition of growth rates of phototrophic microorganisms, especially in PBRs with $k_{L} a$ values smaller than $7 \mathrm{~h}^{-1}$. Only a few studies have examined the $k_{L} a$ of tPBRs, which revealed oxygen mass transfer parameters in the range of $3-7 \mathrm{~h}^{-1}[27,28]$. Integrated airlift systems and advanced degassing units [28-31] are known to improve oxygen mass transfer in tPBRs to prevent oxygen accumulation [26,28]. However, high gas-flow rates and the pumping of the liquid phase may induce shear stress to the cells accompanied by considerable energy costs $[32,33]$.

Mathematical models have been developed to predict the accumulation of oxygen in tPBRs considering the impact on the growth kinetics of microalgae. Rubio et al. [27] introduced a model for estimating DOC profiles in tPBRs that took into consideration oxygen mass transfer characteristics. However, the authors assumed the microalgal oxygen production rate to be average and did not take into account the impacts of dynamic changing illumination intensity or the DOC on the microalgal growth rate [27]. In contrast, Trentin et al. [34] developed a comprehensive model for C. protothecoides to predict biomass productivity in a $\mathrm{tPBR}$ taking into consideration various impact factors such as the DOC and illumination intensity. Although the oxygen mass transfer characteristics of the liquid phase were neglected, their model can predict how several environmental factors and design modifications to the tPBR affect the biomass productivity. To specifically describe the impact of DOCs on photoautotrophic growth, Costache et al. [35] have proposed a kinetic model based on product inhibition, describing the exponential decline in the oxygen production rate $(O P R)$ at an increasing DOC for $S$. almeriensis. The model takes into account the competitive inhibition of RuBisCO's carboxylase function by oxygen (photorespiration), which occurs increasingly at high DOCs [35]. Sforza et al. [36] investigated the extent of inhibition on the photosynthetic activity of the microalgae C. protothecoides at high DOCs and varying illumination intensities and biomass concentrations, indicating that the $O P R$ at rising DOC levels differs in experiments under varying process conditions.

This study aims to quantify the impact of high DOCs on the growth kinetics and cellular phycocyanin content of $A$. platensis PCC7345 using a lab-scale photorespirometric approach. Kinetic parameters derived from photorespirometry were introduced to a simple process model describing photoautotrophic cyanobacterial growth taking into consideration the oxygen mass transfer characteristics in the liquid phase. This information was used to perform an in-silico scale-up study of two different $5000 \mathrm{~L}$ industrial tPBR configurations. 


\section{Materials and Methods}

\subsection{Strain and Cultivation Conditions}

A. platensis PCC7345 was obtained from the Pasteur Culture Collection (PCC, Paris). Cyanobacterial cells were maintained and pre-cultured in a Spirulina medium [SAG Göttingen, Spirulina Medium] grown in $300 \mathrm{~mL}$ Erlenmeyer flasks at $26{ }^{\circ} \mathrm{C}, 150 \mathrm{rpm}$ and $75 \mu \mathrm{mol} \mathrm{m}{ }^{-2} \mathrm{~s}^{-1}$ fluorescent light (light/dark cycles of 16/8 h, WB750, mytron Biound Solartechnik GmbH, Heilbad Heiligenstadt, Germany). Liquid stock cultures were subcultivated weekly.

To prepare A. platensis PCC7345 cultures for respirometric analyses, a 25 L tPBR (MINT Engineering $\mathrm{GmbH}$, Dresden, Germany) was inoculated from shake flasks and cultivated in batch airlift mode $\left(10 \mathrm{~L} \mathrm{~min}^{-1}\right.$ ambient air) for 10 days at room temperature $\left(23-26{ }^{\circ} \mathrm{C}\right)$, leading to a final cell dry weight concentration $\left(c_{x}\right)$ of $1.1 \mathrm{~g} \mathrm{~L}^{-1}$. To obtain cyanobacterial cells under industrially relevant physiological conditions, the $25 \mathrm{~L}$ tPBR cultivation was carried out in a reduced Spirulina medium, replacing macro- and micro-nutrients with an inorganic plant fertilizer. For respirometric analysis, $1 \mathrm{~L}$ samples were taken from the tPBR and adjusted to the desired $c_{x}$ using the reduced Spirulina medium.

\subsection{Cell Dry Weight Concentration $\left(c_{x}\right) \mathcal{E}$ Optical Density $\left(O D_{750}\right)$}

Culture samples of $A$. platensis PCC7345 were analyzed using a GENESYS 150 UV/VIS spectrophotometer (Thermo Fisher, Waltham, MA, USA). The optical density $\left(\mathrm{OD}_{750}\right)$ was measured at $750 \mathrm{~nm}$ and was calibrated against $c_{x}\left[\mathrm{~g} \mathrm{~L}^{-1}\right]$ of A. platensis PCC7345 using the following correlation $(n=3)$ :

$$
c_{x}=0.86 \cdot \mathrm{OD}_{750}
$$

To determine $c_{x}, 15 \mathrm{~mL}$ of $A$. platensis PCC7345 suspension was passed through a glass microfiber filter (VWR International, Delaware Valley, USA, mesh size: $1 \mu \mathrm{m}, \mathrm{n}=3$ ) followed by washing three times using $15 \mathrm{~mL}$ deionized water and drying for $24 \mathrm{~h}$ at $103{ }^{\circ} \mathrm{C}$ (Memmert GmbH + Co.KG, Schwabach, Germany). Finally, the weight difference of dried biomass was determined to calculate $c_{x}$ (Figure S1, Supplementary Materials).

\subsection{Quantification of Incident Illumination Intensity $\left(I_{0}\right)$ and Calculation of Average Illumination} Intensity $\left(I_{a v}\right)$

The incident illumination intensity $I_{0}\left[\mu \mathrm{mol} \mathrm{m} \mathrm{m}^{-2} \mathrm{~s}^{-1}\right]$ was detected by a DK-PHAR 2.010BS PAR-quantum sensor (deka Sensor + Technologie Entwicklungs- und Vertriebgesellschaft $\mathrm{mbH}$, Teltow, Germany). The local illumination intensity $I_{(Z)}\left[\mu \mathrm{mol} \mathrm{m}^{-2} \mathrm{~s}^{-1}\right]$ was calculated using Lambert-Beer's law:

$$
I_{(Z)}=I_{0} \cdot e^{-\left(c_{x} \cdot \varepsilon \cdot Z\right)}
$$

where $I_{0}$ is the incident illumination intensity $\left(\mu \mathrm{mol} \mathrm{m} \mathrm{m}^{-2} \mathrm{~s}^{-1}\right) ; \varepsilon\left(\mathrm{L} \mathrm{g}^{-1} \mathrm{~cm}^{-1}\right)$ is the cell-specific light attenuation coefficient; $c_{x}\left(\mathrm{~g} \mathrm{~L}^{-1}\right)$ the cell dry weight concentration of A. platensis PCC7345; and Z (cm) the light path lengths. The cell-specific light attenuation coefficient $\varepsilon$ was determined experimentally using a measurement chamber developed in-house, as described recently [37]. Briefly, the chamber was filled with $130 \mathrm{~mL}$ of cyanobacterial suspension with $c_{x}$ ranging from 0.12 to $0.84 \mathrm{~g} \mathrm{~L}^{-1}$. An adjustable slide, carrying an encapsulated pyranometer (deka Sensor + Technologie Entwicklungs- und Vertriebgesellschaft $\mathrm{mbH}$, Teltow, Germany) was moved along the light path $(Z)$ while recording the local illumination intensities $I_{(Z)}$, which were used to calculate $\varepsilon$ with the least squares method using MATLAB 2012 (MathWorks, Natick, MA, USA). Since both absorption and scattering effects had to be taken into account at increasing $c_{x}, \varepsilon$ was introduced into the modeling approach with the following correlation:

$$
\varepsilon\left[\mathrm{L} \mathrm{cm}^{-1} \mathrm{~g}^{-1}\right]=\left\{\begin{array}{c}
-6.83 \cdot c_{x}+5.34, \quad c_{x} \leq 0.355 \mathrm{~g} \mathrm{~L}^{-1} \\
-0.045 \cdot c_{x}+3.014, \quad c_{x}>0.355 \mathrm{~g} \mathrm{~L}^{-1}
\end{array}\right.
$$


To calculate the average illumination intensity $I_{a v}$, local intensities $I_{(Z)}$ were averaged for eight light-path lengths $Z$ across the diameter of the desired vessel (bottle or tPBR).

$$
I_{a v}=\frac{\sum_{i=0}^{8} I_{(Z)}}{8}
$$

\subsection{Photorespirometry Analysis}

Photorespirometry was recently developed by Sforza et al. as a quick and simple method to determine the growth kinetics of microalgae $[36,38,39]$, the aim being to examine the effects of high DOCs on microalgae cultures [36].

In this study, respirometry was performed in a $1000 \mathrm{~mL}$ DURAN GLS 80 doublewalled laboratory bottle (diameter: $7 \mathrm{~cm}$, DWK Life Sciences GmbH, Wertheim, Germany) equipped with oxygen, $\mathrm{pH}$ and temperature probes (Figure $1 \mathrm{a}, \mathrm{b}$ ). To avoid gas losses via the headspace, the bottle was filled completely with A. platensis PCC7345 liquid culture. The DOC was detected at short time intervals (10 s) by a GMH 3611 oximeter (GWO 3600 probe, GHM Messtechnik GmbH, Remscheid Germany) and the EBS 20 M monitoring software. The temperature was adjusted at $30{ }^{\circ} \mathrm{C}$ by using a circulating water thermostat mixing the cell suspension by a magnetic stirrer at $300 \mathrm{rpm}$. To decrease the DOC, a $\mathrm{CO}_{2} / \mathrm{N}_{2}(20 \% v / v)$ mixture was sparged into the liquid phase using sintered stone. The bottle cap was sealed with Teflon tape to create an airtight system. The photorespirometry set-up was illuminated on one side by plant-growth LEDs optimized for photosynthetically active radiation. $I_{0}$ was measured at the surface of the bottle using a PAR-quantum sensor DK-PHAR 2.010BS (deka Sensor + Technologie Entwicklungs- und Vertriebgesellschaft mbH, Teltow, Germany). All respirometric experiments were performed in a light-proof box to provide constant illumination conditions (Figure 1b).

The respirometric routine reported by Sforza et al. [36] in 2020 was modified by introducing an exposure phase as indicated in Figure 1c. The routine was carried out in three phases: (1) a reference phase exposing the cells to intermittent light/dark illumination cycles (reference values for oxygen production rate $(O P R)$ and oxygen consumption rate $(O C R)),(2)$ a continuous light phase providing supersaturated DOC conditions and (3) an exposure phase to investigate how high DOCs affected the cellular phycocyanin content. Before the reference phase was initiated, the DOC was adjusted to approx. $4.5 \mathrm{mgO}^{-1}$ by sparging a $\mathrm{CO}_{2} / \mathrm{N}_{2}$ mixture $(20 \% \mathrm{v} / \mathrm{v})$ followed by five alternating light/dark illumination cycles (10 min per phase). The data from the first light/dark cycle were discarded to take into account the cells' adaptation to new environmental conditions. OPR data were derived from the reference phase by the following correlation taking into consideration the oxygen mass transfer coefficient $k_{L} a$ and the concentration difference of the current DOC $\left(c_{\mathrm{O}_{2}}\right)$ and the solubility concentration in the liquid $c_{\mathrm{O}_{2}}^{*}$ :

$$
r_{\mathrm{O}_{2}}=\frac{\mathrm{d} c_{\mathrm{O}_{2}}}{\mathrm{~d} t}=k_{L} a \cdot\left(c_{\mathrm{O}_{2}}^{*}-c_{\mathrm{O}_{2}}\right)+O P R
$$

The solubility concentration of oxygen $c_{\mathrm{O}_{2}}^{*}$ in water depends on the temperature and can be calculated by Henry's Law [40]:

$$
c_{\mathrm{O}_{2}}^{*}=\mathrm{H}_{\mathrm{O}_{2}} \cdot p_{\mathrm{O}_{2}}
$$

where $H_{\mathrm{O}_{2}}$ is the temperature-dependent Henry's law constant and $p_{\mathrm{O}_{2}}$ the oxygen partial pressure in line with [40]:

$$
H_{\mathrm{O}_{2}}=H_{r e f} \cdot e^{C \cdot\left(\frac{1}{T}-\frac{1}{T_{r e f}}\right)}
$$

The oxygen mass transfer coefficient $k_{L} a$ of the photorespirometry set-up (Figure $1 \mathrm{~b}$, $T=30{ }^{\circ} \mathrm{C}, p_{\mathrm{O}_{2}}=0.21 \mathrm{~atm}$ ) was determined to $0.187 \pm 0.009 \mathrm{~h}^{-1}$ using the log deficit procedure (ASCE, 1993 [41]), as proposed by Sforza et al. [39]. Due to the low mass transfer coefficient of the setup, this parameter was neglected in further calculations. OPR data 
were connected to the adjusted $c_{x}$, which was assumed to remain constant during the reference phase.

(a)

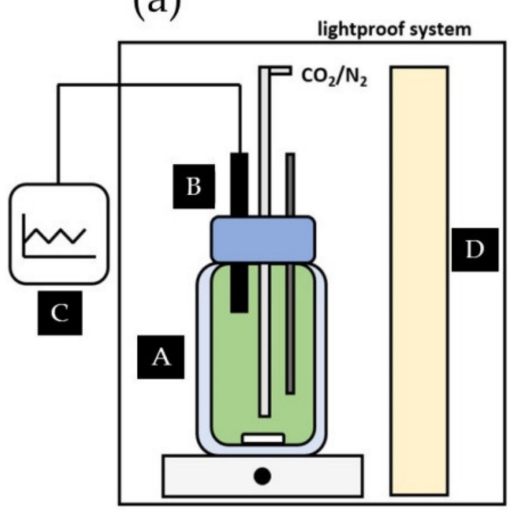

(b)

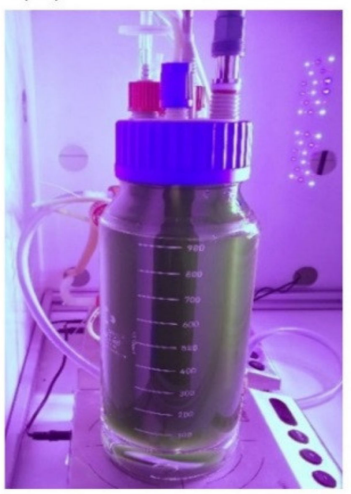

(c)

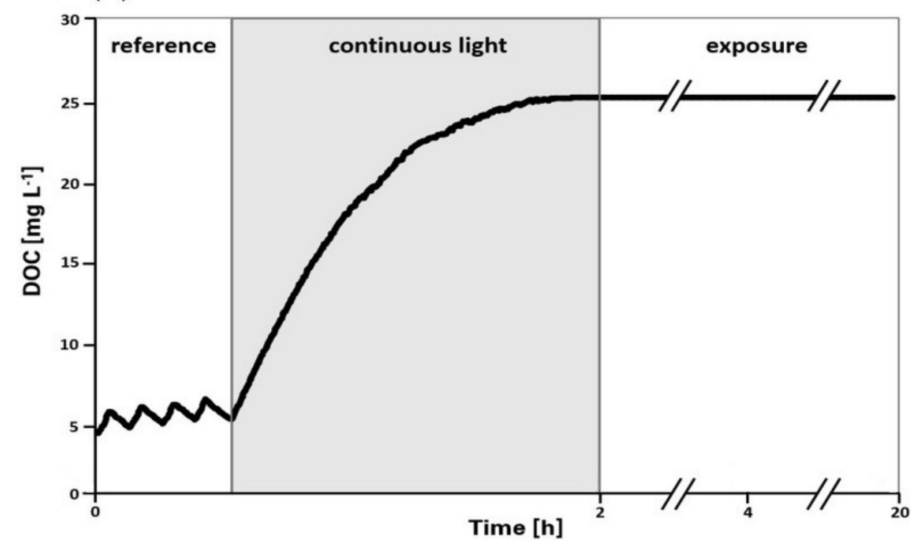

Figure 1. Photorespirometry setup (a) Schema of experimental setup including (A) a double-walled glass vessel, (B) an airtight cap equipped with $\mathrm{pH}$, temperature and oxygen probe, (C) external monitoring software, and (D) photosynthetically active radiation LED light source; (b) Photograph of a running experiment; (c) Example of course of photorespirometry routine divided into (a) reference phase; (b) continuous illumination phase and (c) exposure phase.

Respirometric tests were conducted under varying process conditions, i.e., at $I_{0}$ of 100, 150 and $400 \mu \mathrm{mol} \mathrm{m}^{-2} \mathrm{~s}^{-1}$ and $c_{x}$ of $0.1,0.5,0.8$ and $1 \mathrm{~g} \mathrm{~L}^{-1}$. Using Equation (4), the range of $I_{a v}$ for the respirometry setup results in 13-131 $\mu \mathrm{mol} \mathrm{m} \mathrm{m}^{-2} \mathrm{~s}^{-1}$. The impact of $I_{a v}$ on the photosynthetic activity, indicated by the $c_{x}$-related $O P R$, can be described by the illumination half-saturation constant, $K_{L}\left(\mu \mathrm{mol}\right.$ photons $\left.\mathrm{m}^{-2} \mathrm{~s}^{-1}\right)$ and the $c_{x}$-related maximum rate of photosynthesis, $O P R_{\max , \text { spec }}$ :

$$
\frac{O P R}{c_{x}}=O P R_{\max , \text { spec }} \cdot \frac{I_{a v}}{I_{a v}+K_{L}}
$$

This model approach neglects photoinhibition effects under high $I_{a v}$ conditions, which were not observed in this study. $K_{L}$ and $O P R_{\max \text {,spec }}$ were obtained by fitting experimental data on the reference phase using the least square method in MATLAB ${ }^{\circledR} 2012$ (MathWorks, USA). To take into account the compensation point, at which gross OPR by photosynthesis and the oxygen consumption rate by basal respiration is balanced out (net $O P R=0$ ), OPR data were offset in line with the examples used by Vonshak (1997) [42] before applying fitting routines in MATLAB 2012 (Natick, MA, USA). 


\subsection{In-Vivo Phycocyanin Quantification of Suspended Cells}

The quantification of the cellular phycocyanin content of cyanobacteria is usually carried out by consecutive steps of physical or chemical cell disruption (physical steps include ultrasound, high-pressure homogenization, cavitation, osmolysis and freezing cycles; chemical steps include acid/alkali treatments, detergents and enzymes), followed by buffer extraction, salt precipitation, phase separation and spectrometric quantification using empirical equations such as the Bennet and Bogorad correlation [43]. These routines are time-consuming and depend on the efficiency of the individual process steps. For that reason, in this work an optical in-vivo method was established for quantifying the intracellular phycocyanin content while avoiding the steps of cell disruption and phycocyanin purification.

The cellular phycocyanin content $c_{P C}\left(\mathrm{mg} \mathrm{g}^{-1}\right)$ of A. platensis PCC7345 was quantified using fluorescence spectrometry (LS-55, Perkin Elmer Inc., Waltham, MA, USA). Culture samples were diluted using saline solution to achieve a final $\mathrm{OD}_{750}$ of 0.1 in a $3 \mathrm{~mL}$ cuvette that was clear on all sides and made from polystyrene. The diluted cell suspension was homogenized in the cuvette by a magnetic stirrer during the fluorescence measurement. The intracellular phycocyanin was excited with light in the spectral range of 600-630 nm; the maximum of phycocyanin absorption (step with $5 \mathrm{~nm}$, measurement speed: $1200 \mathrm{~nm} \mathrm{~min}{ }^{-1}$ ). Fluorescence emission was detected ranging from 650-670 nm, yielding a fluorescence heat map (Figure S2, Supplementary Materials). The peak fluorescence intensity $\left(I_{f, \max }\right)$ at $615-620 \mathrm{~nm}$ was detected in triplicate and used to calculate the cellular phycocyanin content employing the following correlation (Figure S3, Supplementary Materials):

$$
c_{P C}=04484 \cdot I_{f, \max }
$$

Statistical analyses of in-vivo $c_{P C}$ quantification were performed in the form of twoway analyses of variance (ANOVA) to investigate how the exposure time and the cultivation conditions influenced $c_{P C}$ using the software GraphPad prism and applying a significance level of $5 \%(p<0.05)$. The $c_{P C}$ was determined after 2,4 , and $20 \mathrm{~h}$ of high DOC exposure as shown in Figure 1c.

\subsection{Modeling Approaches}

\subsubsection{Modeling of Respirometric Data}

In the literature, only a few models are presented that describe how high DOCs affect the OPR of photosynthetically active organisms. Among them, Costache et al. [35] and Sforza et al. [36] have introduced models for studying OPR and DOC correlation.

Sforza et al. [36] developed a comprehensive model taking into account phenomena that are believed to induce inhibitory effects at high DOCs, involving oxygen consumption due to basal respiration expressed by the oxygen respiration rate $\left(O C R_{\text {resp }}\right)$, the positive photosynthetic oxygen production rate $\left(O P R_{p h}\right)$ and the oxygen inhibition rate $\left(O C R_{i n h}\right)[36]:$

$$
O P R_{n e t}=O P R_{p h}-O C R_{r e s p}-O C R_{i n h}
$$

$O P R_{p h}$ was described as a function of $I_{a v}$, the maximum specific oxygen rate $\mu_{O_{2}}$ $\left(\mathrm{d}^{-1}\right)$ and the $\mathrm{O}_{2}: \mathrm{CO}_{2}$ ratio to include the effects of photorespiration as a counterpart of photosynthesis [36]:

$$
O P R_{p h}=\mu_{\mathrm{O}_{2}} \cdot f\left(I_{a v}\right) \cdot c_{x} \frac{{ }^{c} \mathrm{CO}_{2}}{K_{\mathrm{CO}_{2}}\left(1+\frac{c_{\mathrm{O}_{2}}}{K_{P R}}\right)+c_{\mathrm{CO}_{2}}}
$$


The oxygen respiration rate $\left(O C R_{\text {resp }}\right)$ in their model can be described by a Monodtype function depending on the DOC $\left(c_{\mathrm{O}_{2}}\right)$ including the maximum oxygen respiration rate $k_{\text {resp }}\left(\mathrm{d}^{-1}\right)$ and the respiration half-saturation constant $K_{M, O 2}\left(\mathrm{mg} \mathrm{L}^{-1}\right)[36,44]$ :

$$
O C R_{r e s p}=k_{r e s p} \cdot \frac{c_{\mathrm{O}_{2}}}{K_{M, O 2}+c_{\mathrm{O}_{2}}} \cdot c_{x}
$$

Analyzing C. protothecoides, Sforza et al. [36] found an exponential correlation to describe the oxygen inhibition rate $O C R_{\text {inh }}$ under varying cultivation conditions, introducing the oxygen inhibition coefficient $k_{i n h}\left(\mathrm{~d}^{-1}\right)$ and oxygen inhibition exponent $\zeta\left(\mathrm{L} \mathrm{mg}^{-1}\right)$ [36]:

$$
\frac{O C R_{i n h}}{c_{x}}=k_{i n h} \cdot e^{\xi^{*} \cdot \mathrm{CO}_{2}}
$$

The model introduced by Costache et al. [35] originates in a description of product inhibition to take into account the competitive inhibition of the carboxylase function of $\mathrm{RuBisCO}$ by oxygen during photorespiration. By applying the oxygen inhibition constant $K_{2}\left(\mathrm{mg} \mathrm{L}^{-1}\right)$ and the form factor $z(-)$, the normalized biomass-related $\overline{O P R}$ is described as a function of the $\mathrm{DOC}\left(\mathrm{c}_{\mathrm{O}_{2}}\right)$ [35]:

$$
\overline{\mathrm{OPR}\left[c_{\mathrm{O}_{2}}\right]}=1-\left(\frac{\mathrm{c}_{\mathrm{O}_{2}}}{\mathrm{KO}_{2}}\right)^{z}
$$

\subsubsection{Photoautotrophic Growth Modeling}

The biomass growth rate $r_{x}\left(g_{x} \mathrm{~L}^{-1} \mathrm{~h}^{-1}\right)$ of microorganisms is described by the specific growth rate $\mu\left(\mathrm{h}^{-1}\right)$ and the cell dry weight concentration $c_{x}\left(\mathrm{~g}_{\mathrm{x}} \mathrm{L}^{-1}\right)$ :

$$
r_{x}=\mu \cdot c_{x}
$$

Assuming that there is an excess supply of nutrients and carbon source $\left(\mathrm{HCO}^{-3}\right)$, a constant $\mathrm{pH}$ and constant temperature conditions, $\mu\left(\mathrm{h}^{-1}\right)$ can be expressed as a function of the average illumination intensity $I_{a v}\left(\mu \mathrm{mol} \mathrm{m}{ }^{-2} \mathrm{~s}^{-1}\right)$, the maximum growth rate $\mu_{\max }\left(\mathrm{h}^{-1}\right)$ and the half-saturation constant $K_{L}\left(\mu \mathrm{mol}\right.$ photons $\left.\mathrm{m}^{-2} \mathrm{~s}^{-1}\right)$ :

$$
\mu=\mu_{\max } \cdot \frac{I_{a v}}{I_{a v}+K_{L}}
$$

It was reported that $\mathrm{OPR}\left(\mathrm{r}_{\mathrm{O}_{2}}\right)$ correlates to the photoautotrophic growth rate $\mu$ of cyanobacteria $[25,45]$. Therefore, OPR can be identified by the yield coefficient $Y_{\frac{\mathrm{O}_{2}}{x}}$ :

$$
O P R=r_{\mathrm{O}_{2}}=Y_{\frac{\mathrm{O}_{2}}{x}} \cdot r_{x}
$$

Applying the model developed by Costache et al. [35], the rate of biomass growth can be formulated as a function of the $\mathrm{DOC}\left(c_{\mathrm{O}_{2}}\right)$ :

$$
r_{x}=\mu_{\max } \cdot \frac{I_{a v}}{I_{a v}+K_{L}} \cdot\left(1-\left(\frac{c_{O_{2}}}{K O_{2}}\right)^{z}\right) \cdot c_{x}
$$

\subsection{In-Silico Scale-Up Study at Industry-Scale tPBR}

For in-silico studies on biomass growth of A. platensis PCC7345 in large-scale cultivation systems, a horizontal tPBR system for industrial use is assumed, consisting of a solar array, a degassing unit and a harvesting unit (Figure 2). The continuous system is based on the partial recycling of biomass that is grown in a solar array consisting of 4 tubes with a length of $450 \mathrm{~m}$, a diameter of $6 \mathrm{~cm}$ and a total volume of $5000 \mathrm{~L}$. The tubes can be operated in parallel or linked in series, resulting in a total tube length of $1800 \mathrm{~m}$. Biomass growth and oxygen accumulation in the solar unit lead to an increased biomass concentration $c_{x, \text { out }}$ 
and DOC $\left(c_{\mathrm{O}_{2}, \text { out }}\right)$ at the end of the tube compared to the tube inlet $\left(c_{x, 0} ; c_{\mathrm{O}_{2}, 0}\right)$. A sub-flow of the biomass-enriched suspension is removed from the system by a harvesting unit $\left(\dot{V}_{H}\right)$. The residual flow $\left(\dot{V}_{r e c}\right)$ is recycled to a degassing unit, where the DOC is reduced to air saturation $\left(c_{\mathrm{O}_{2}, 0}\right)$ and the suspension is enriched with fresh medium $\left(\dot{V}_{I}\right)$, before being recycled to the solar unit. Assuming that biomass growth occurs solely in the tubes of the solar unit and that operation is steady-state, then, in line with the plug flow reactor model, the biomass growth over the tube length $l$ (running coordinate) can be described by the flow velocity $v$ in the solar loop and the biomass growth rate $r_{x}$ [34]:

$$
\frac{d c_{x}}{d l}=\frac{1}{v} \cdot r_{x}
$$

(a)

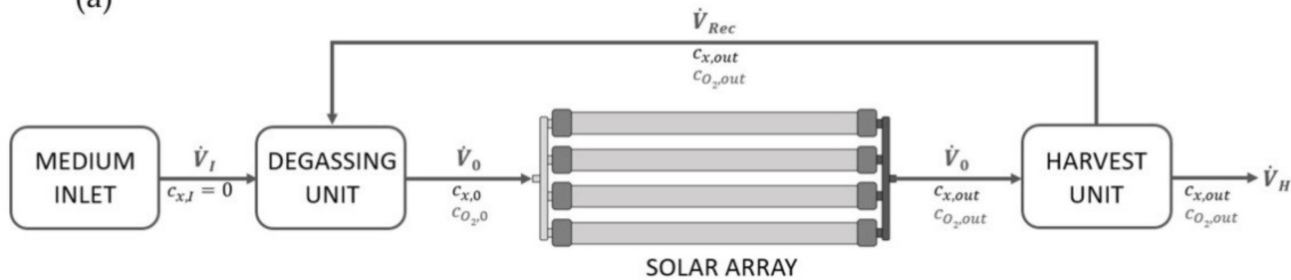

(b)
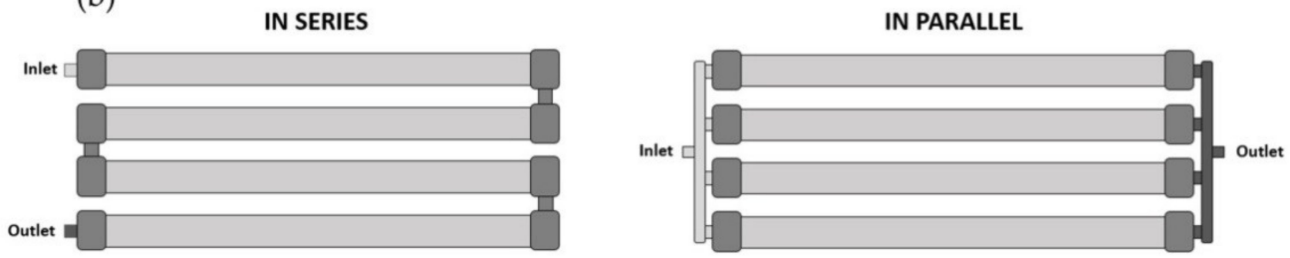

Figure 2. (a) Assumptions behind a continuous operating tPBR system for an in-silico scale up study, (b) tPBR system in a serial configuration with a total tube length of $1800 \mathrm{~m}$ and in a parallel configuration with a total tube length of $450 \mathrm{~m}$.

The accumulation of oxygen over the tube length depends on the $O P R\left(r_{\mathrm{O} 2}\right)$; the gas-liquid mass transfer of oxygen in the system, and the gas hold-up $\varepsilon_{g}[27,46]$ :

$$
\frac{d c_{O_{2}}}{d l}=O P R=\frac{1}{v} \cdot\left(k_{L} a \cdot\left(c_{O_{2}}^{*}-c_{O_{2}}\right)+r_{O_{2}} \cdot\left(1-\varepsilon_{g}\right)\right)
$$

Taking into account the increase in the biomass concentration over the tube length and the residence time $\tau$ in the solar loop, which can be determined by connecting the solar loop length $L$ to the flow velocity $v$, the volumetric productivity $P_{x}$ of the continuously operated tPBR can be obtained. The increase in biomass over the tube length can be derived from the difference between the biomass concentration at the outlet of the solar loop $c_{x, o u t}$ and that at the inlet $c_{x, 0}$ :

$$
P_{x}=\frac{c_{x, o u t}-c_{x, 0}}{\tau}
$$

\section{Results and Discussion}

3.1. Impact of High Dissolved Oxygen Concentration (DOC) on the Oxygen Production Rate (OPR) of A. platensis PCC7345

Photorespirometric analyses were carried out to study how rising DOCs influence the OPR of A. platensis PCC7345 under varying $c_{x}\left(0.1,0.5\right.$, and $\left.1.0 \mathrm{~g} \mathrm{~L}^{-1}\right)$ and incident illumination conditions $\left(I_{0}=100,150\right.$ and $400 \mu \mathrm{mol} \mathrm{m} \mathrm{m}^{-2} \mathrm{~s}^{-1}$ equal to $I_{a v}$ of $\left.13-131 \mu \mathrm{mol} \mathrm{m}^{-2} \mathrm{~s}^{-1}\right)$.

Figure 3 a presents the $c_{x}$-related $O P R$ and rate of oxygen consumption due to basal respiration $(O C R)$ obtained in experiments with varying average illumination conditions. 


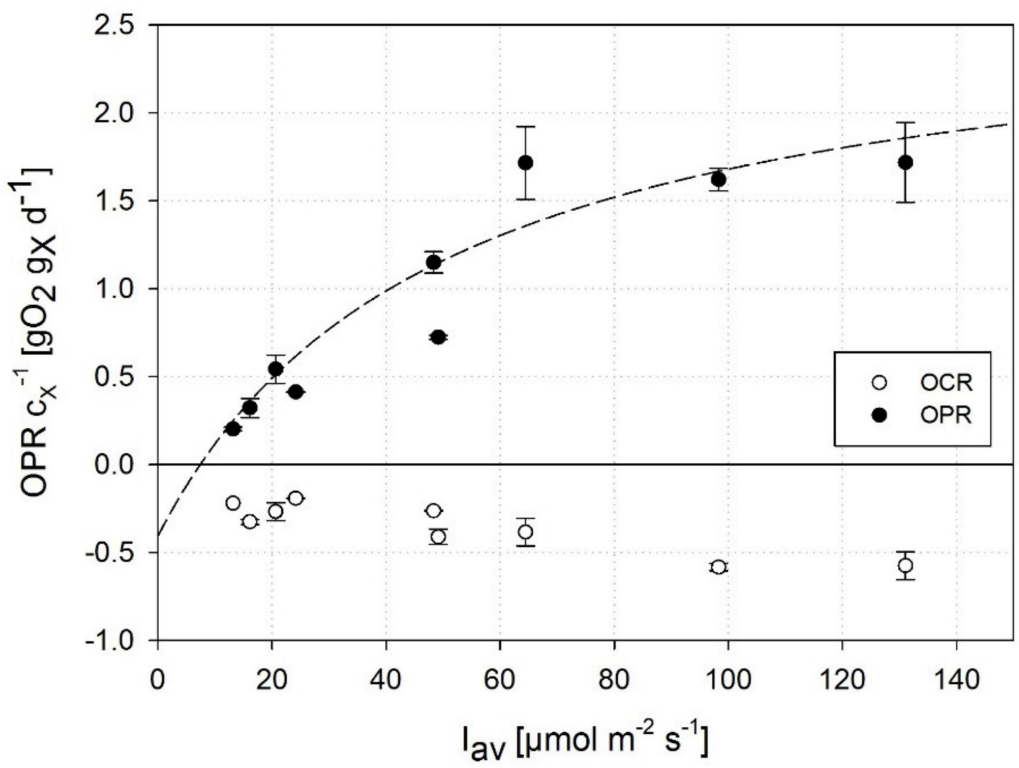

Figure 3. Biomass-related oxygen production rate at an increasing average illumination intensity $\left(I_{a v}\right)$ separated into measurable net photosynthetic OPR (positive) and respirometric OCR (negative): determination of the photosynthetic half-saturation constant $K_{L}\left(49.4 \mu \mathrm{mol} \mathrm{m}^{-2} \mathrm{~s}^{-1}\right.$;

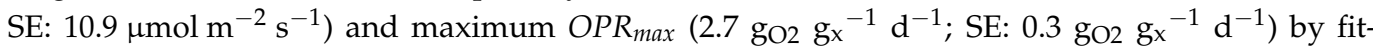
ting to a MONOD-type model. Data were obtained during light/dark cycles of the reference phase under air-saturated DOCs. Error bars represent standard deviation of two independent experiments.

The OPR increased at a constant rate under $I_{a v}$ conditions $<64 \mu \mathrm{mol} \mathrm{m}^{-2} \mathrm{~s}^{-1}$ but remained at a constant level at $I_{a v}>64 \mu \mathrm{mol} \mathrm{m}^{-2} \mathrm{~s}^{-1}$ indicating a light-saturated state. As described in several studies [45,47-49] for different phototrophic microorganisms, the dark respiration rate $O C R$ correlates with their growth rate and the availability of photosynthetically active radiation, indicated by a $40 \%$ increase in OCR at $131 \mu \mathrm{mol} \mathrm{m} \mathrm{m}^{-2} \mathrm{~s}^{-1}$ compared to the low $I_{a v}$ conditions of $13 \mu \mathrm{mol} \mathrm{m}^{-2} \mathrm{~s}^{-1}$ in this study. Photoinhibitory effects were not observed under the illumination conditions considered in this study (max. $I_{0}=400 \mu \mathrm{mol} \mathrm{m}^{-2} \mathrm{~s}^{-1}$, max. $I_{a v}=131 \mu \mathrm{mol} \mathrm{m}^{-2} \mathrm{~s}^{-1}$ ). Based on photorespirometric data on A. platensis PCC7345, the half-saturation constant $K_{L}$ was quantified to $49.4 \mu \mathrm{mol} \mathrm{m}^{-2} \mathrm{~s}^{-1}$ (SE: $10.9 \mu \mathrm{mol} \mathrm{m}^{-2} \mathrm{~s}^{-1}$; Equation (8)). According to Vonshak (1997), the light dependence of photoautotrophic growth of A. platensis, and thus the related $O P R_{\max }$ and $K_{L}$ value depend strongly on the experimental conditions, as photoadaptation effects, for example, may affect growth kinetics [42]. Moreover, $K_{L}$ values reported in the literature are derived from varying modeling approaches $[50,51]$ or are based on incident illumination intensities (in contrast to the use of average illumination conditions $I_{a v}$ in this study). The half-saturation constant $K_{L}$ of A. platensis was quantified in recent studies as approx. $90 \mu \mathrm{mol} \mathrm{m}{ }^{-2} \mathrm{~s}^{-1}$ assuming incident illumination intensities [52,53], whereas Vonshak (1997) proposed that the onset of light saturation in different Spirulina strains occurs at incident illumination intensities of 115-165 $\mu \mathrm{mol} \mathrm{m}^{-2} \mathrm{~s}^{-1}$ [42]. However, the impact of cell-specific light attenuation under dynamically changing $c_{x}$ conditions due to mutual shading effects by the cells has not been taken into consideration in most studies.

\subsection{Correlation of DOC and OPR of A. platensis PCC7345}

Photorespirometry is a powerful tool for rapidly and reproducibly analyzing how environmental factors such as a high DOC affects the cellular physiology of photoautotrophic cells.

Figure 4 shows the course of a normalized OPR at DOCs rising to $24 \mathrm{mg} \mathrm{L}^{-1}$ (approx. $300 \%$ air saturation) with varying $c_{x}$ and $I_{0}$ conditions. The data indicate that a rising concentration of dissolved oxygen considerably affects the OPR. However, the inhibition kinetics are highly dependent on both the illumination conditions and adjusted $c_{x}$. An 
exponential decrease in a normalized $O P R$ was detected when low $c_{x}$ were exposed to incident illuminations $>150 \mu \mathrm{mol} \mathrm{m} \mathrm{m}^{-2} \mathrm{~s}^{-1}$ yielding a full inhibition of the OPR at a DOC of approx. $10 \mathrm{mg} \mathrm{L}^{-1}$. The inhibitory effect of the DOC declined at higher $c_{x}\left(0.5 \mathrm{~g} \mathrm{~L}^{-1}\right.$ and $1.0 \mathrm{~g} \mathrm{~L}^{-1}$ ) or under lower $I_{a v}$ conditions, causing a linear decrease in the normalized $O P R$ up to a critical DOC of about $22 \mathrm{mg} \mathrm{L}^{-1}$. The OPR inhibition kinetics of Figure 4 indicate that $A$. platensis PCC7345 is highly sensitive to rising DOCs at low $c_{x}$, which are representative for early phases of large-scale cultures; however, the effect is weakened under higher $c_{x}$ conditions.

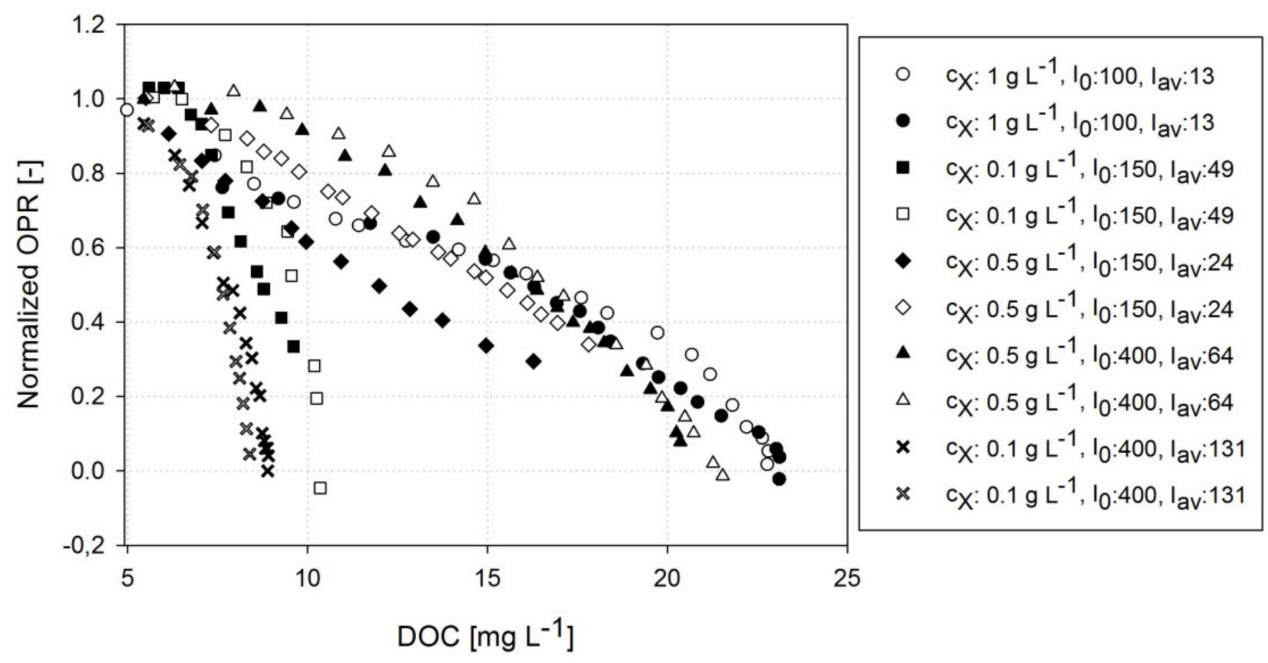

Figure 4. Normalized OPR at increasing DOCs. Data were obtained during the continuous illumination phase of the photorespirometry experiments under varying cell dry weight concentrations and illumination conditions. Two independent experimental runs are presented per condition (legend).

A similar exponential decrease in OPRs has been reported in recent studies for microalgae such as S. almeriensis [35] or C. protothecoides [36] showing a comparable maximum DOC for C. protothecoides (20-30 $\left.\mathrm{mg} \mathrm{L}^{-1}\right)$. The physiological reasons for inhibitory effects at high DOCs have been discussed variously in the literature. First, reversible effects such as photorespiration have been suggested as a cause of photosynthesis inhibition in microalgae at high DOCs $[35,36]$. Second, enhanced photo-oxidative processes are known to impair the photosynthetic activity of cells. It was reported that a high DOC is able to initialize destructive photo-oxidative effects even at low illumination intensities [24,54], i.e., the generation of harmful reactive oxygen species (ROSs) by Mehler (-peroxidase) reactions can affect important cellular repair and protection mechanisms [55,56] and interact with photosynthesis pigments [57]. In a previous study, Allahverdiyeva et al. [58] showed that the extent of "Mehler-like" reactions of cyanobacteria correlated with the illumination intensity. Raven et al. [59] stated that the degree of oxygen uptake, and the ROS generation by Mehler-peroxidase reactions, is significantly higher for cyanobacteria compared to eukaryotic green microalgae. Table 1 provides an overview of recent studies addressing how DOCs affect the growth kinetics and biomass composition of phototrophic microorganisms.

It was proposed that high DOCs do not affect the pigment content of microalgae at low illumination intensities [26,60]. However, for cyanobacteria the authors found a significant reduction in the cellular pigment content (e.g., chlorophyll, phycocyanin) at rising DOCs and low illumination intensities [61,62]. Table 1 reveals that the growth rate of $A$. platensis seems to be generally less affected by high DOCs compared to eukaryotic microalgae. Nevertheless, it was recommended to avoid DOCs $>30 \mathrm{mg} \mathrm{L}^{-1}[25,63]$ or even $>20 \mathrm{mg} \mathrm{L}^{-1}$ [64] when culturing A. platensis, which shows the need for a systematic analysis of this interplay of the process parameters. To take an example, the daily productivity of an outdoor tPBR cultivation was reduced by approximately $20 \%$ at high DOCs (53.0 $\pm 9.4 \mathrm{mg}$ $\left.\mathrm{L}^{-1}\right)$ compared to similar process conditions at lower DOCs $\left(20.8 \pm 1.8 \mathrm{mg} \mathrm{L}^{-1}\right)$ [64]. 
Table 1. Overview of the impact of highly dissolved oxygen concentrations (DOCs) on growth parameters such as the specific growth rate $\mu$, volumetric biomass productivity $P_{x}$, oxygen production rate $O P R$, biomass concentration $c_{x}$ and pigment composition of different microalgae and cyanobacteria. SS: sub-saturation light; NS: near-saturation light; IL: inhibiting light; $c_{C h l}$ : chlorophyll content; $c_{C \text { ar }}$ : carotenoid content; $c_{P C}$ : phycocyanin content; $c_{P}$ : protein content, $\mathrm{Y}(\mathrm{II})$ : effective PS II quantum yield; the unit $\mu \mathrm{E}$ corresponds to $\mu \mathrm{mol} \mathrm{m} \mathrm{m}^{-2} \mathrm{~s}^{-1}$.

\begin{tabular}{|c|c|c|c|c|c|}
\hline Microorganism & $\begin{array}{c}\text { Culture } \\
\text { Conditions }\end{array}$ & $\begin{array}{c}\text { DOC } \\
\left(\mathrm{mg} \mathrm{L}^{-1}\right)\end{array}$ & $\begin{array}{l}\text { Effects on the Growth } \\
\left(\mu, P_{x}, O P R, c_{x}\right)\end{array}$ & $\begin{array}{l}\text { Effects on Pigment } \\
\text { Composition }\end{array}$ & Source \\
\hline \multirow[t]{2}{*}{$\begin{array}{l}\text { Neochloris } \\
\text { oleoabundans }\end{array}$} & $\begin{array}{c}200 \mu \mathrm{E} \text { (SS); } \\
25^{\circ} \mathrm{C}\end{array}$ & $\begin{array}{l}\approx 26 \\
\approx 35\end{array}$ & $\begin{array}{c}\text { decrease in } \mu \text { by: } \\
<2 \% \\
\approx 23 \%\end{array}$ & \multirow[b]{2}{*}{$\begin{array}{l}\text { no impact on } c_{C h l} \text { and } \\
c_{C a r}\end{array}$} & [65] \\
\hline & $\begin{array}{c}500 \mu \mathrm{E}(\mathrm{NS}) \\
25{ }^{\circ} \mathrm{C}\end{array}$ & $\begin{array}{l}\approx 17 \\
\approx 26 \\
\approx 35\end{array}$ & $\begin{array}{l}\approx 15 \% \\
\approx 32 \% \\
\approx 50 \%\end{array}$ & & [60] \\
\hline Nannochloropsis sp. & $\begin{array}{c}100 \mu \mathrm{E}(\mathrm{SS}) ; \\
25^{\circ} \mathrm{C}\end{array}$ & $\begin{array}{l}\geq 6 \\
\approx 21\end{array}$ & $\begin{array}{l}\text { linear decrease in } \mu \\
\quad \approx 38 \% \text { of } \mu \text { left }\end{array}$ & \multirow[b]{2}{*}{ no impact on pigments } & [66] \\
\hline Chlorella vulgaris & $\begin{array}{c}250 \mu \mathrm{E} \\
25^{\circ} \mathrm{C}\end{array}$ & $\begin{array}{l}\leq 25 \\
31 \\
\leq 9\end{array}$ & $\begin{array}{l}\text { no impacts } \\
30 \% \text { decrease in } P_{x} \\
\text { maximum OPR }\end{array}$ & & [26] \\
\hline $\begin{array}{l}\text { Scenedesmus } \\
\text { almeriensis }\end{array}$ & $\begin{array}{c}200 \mu \mathrm{E}(\mathrm{SS}) \\
25^{\circ} \mathrm{C}\end{array}$ & $\begin{array}{c}9-23 \\
>23 \\
32\end{array}$ & $\begin{array}{c}\text { decrease in } O P R \leq 20 \% \\
\text { exponential decline } \\
O P R=0\end{array}$ & & \multirow[b]{2}{*}{ [36] } \\
\hline \multirow[t]{3}{*}{$\begin{array}{c}\text { Chlorella } \\
\text { protothecoides }\end{array}$} & $\begin{array}{c}150 \mu \mathrm{E}(\mathrm{SS}) \\
24{ }^{\circ} \mathrm{C}\end{array}$ & $\begin{aligned} & \leq 16 \\
& >16 \\
\approx & 21-26\end{aligned}$ & $\begin{array}{c}\text { constant } O P R \\
\text { exponential decline } \\
O P R=0\end{array}$ & & \\
\hline & $1000 \mu \mathrm{E}(\mathrm{NS})$ & $\approx 27$ & $O P R=0$ & & \\
\hline & $1500 \mu \mathrm{E}(\mathrm{IL})$ & $\approx 30$ & $O P R=0$ & & \\
\hline Arthrospira maxima & $\begin{array}{c}\approx 125 \mu \mathrm{E}, \\
30{ }^{\circ} \mathrm{C}\end{array}$ & $\approx 16$ & no significant effects & $\begin{array}{c}\text { reduction of } \\
c_{P}(50 \%) ; \\
c_{P C}(70 \%), \\
c_{C h l}(20 \%)\end{array}$ & [62] \\
\hline \multirow[t]{3}{*}{ Arthrospira platensis } & $\begin{array}{c}\approx 140 \mu \mathrm{E}(\mathrm{SS}) \\
\quad 30{ }^{\circ} \mathrm{C}\end{array}$ & $\begin{array}{l}\approx 10 \\
\approx 20 \\
\approx 30 \\
\approx 40\end{array}$ & $\begin{array}{c}\text { decrease in } \mu \text { by: } \\
10 \% \\
20 \% \\
33 \% \\
46 \% \\
\text { decrease in } \mu \text { by: }\end{array}$ & \multirow[t]{2}{*}{$\begin{array}{c}\text { reduction of } c_{P C} ; c_{C h l} \\
c_{C a r} \text { (all up to approx. } \\
80 \% \text { ) }\end{array}$} & [61] \\
\hline & $\begin{array}{c}32 \mu \mathrm{E}(\mathrm{SS}) \\
30{ }^{\circ} \mathrm{C}\end{array}$ & $\begin{array}{l}\approx 40 \\
\approx 60 \\
\geq 80\end{array}$ & $\begin{array}{c}\approx 13 \% \\
\approx 25 \% \\
\text { no growth }\end{array}$ & & [67] \\
\hline & $\begin{array}{c}350 \mu \mathrm{E} \\
\text { (NS-IL); } \\
35^{\circ} \mathrm{C}\end{array}$ & 36 & $\begin{array}{l}\max .18 \% \text { lower } c_{x} ; \\
\text { chlorotic after long } \\
\text { exposure }(>32 \mathrm{~h})\end{array}$ & reduction of $c_{C h l}(30 \%)$ & [64] \\
\hline
\end{tabular}

\subsection{Estimating Kinetic Parameters with Photorespirometry}

To study how the DOC affects growth kinetics, photorespirometry data were analyzed in line with Sforza et al. [36]. Since photorespirometry experiments carried out under carbon limitation ( $\mathrm{N}_{2}$ sparging, data not shown) revealed no significant impact on OPR trends at rising DOCs, the $O P R_{p h}$ term used by Sforza et al. [36] (Equation (11)) was assumed to be constant for A. platensis PCC7345 in this study and was calculated from the sum of OPR and $O C R$ data obtained during the reference phase under moderate oxygen conditions.

To quantify the $O C R_{\text {resp }}$ - the negative contribution caused by basal respiration(Equation (12)) and the $O P R_{\text {net }}$ (Equation (10)), $O C R$ data of the reference phase (Equation (12): $k_{\text {resp }}=0.266 \mathrm{~d}^{-1}$ SE: $0.006 \mathrm{~d}^{-1} ; K_{M, O 2}=0.181 \mathrm{mg} \mathrm{L}^{-1}$ SE: $0.029 \mathrm{mg} \mathrm{L}^{-1}$ imply constant $O C R$ data in the DOC range of air saturation and higher), and OPR data on the continuous 
illumination phase were applied, respectively. Thus, the inhibitory effect at high DOCs expressed by $O C R_{i n h}$ was derived following Equation (10).

\subsubsection{Model by Sforza et al.}

The experimental data on $c_{x}$-related $O C R_{i n h}$ are shown in Figure 5. Significant differences were observed between $c_{x}$-related $O C R_{i n h}$ for A. platensis PCC7345 in experiments performed under different process conditions (Figures 3 and 4), indicating that $O C R_{\text {inh }}$ of A. platensis PCC7345 cannot be characterized by one set of kinetic parameters as shown for microalgae (Sforza et al. [36]; Figure 5b). Both the oxygen inhibition coefficient $k_{\text {inh }}$ and the oxygen inhibition exponent $\zeta$ ranged between $5.72 \times 10^{-5} \mathrm{~d}^{-1}$ and $5.24 \times 10^{-2} \mathrm{~d}^{-1}$; and $0.11 \mathrm{~L} \mathrm{mg}^{-1}$ to $1.25 \mathrm{~L} \mathrm{mg}^{-1}$, respectively. To conclude, in contrast to the study by Sforza et al. [36], the oxygen inhibition rate $O C R_{\text {inh }}$ was found to be light-dependent for A. platensis PCC7345 and the need was identified to take into account both the illumination intensity and $c_{x}$ conditions of each experimental setup.

(a)

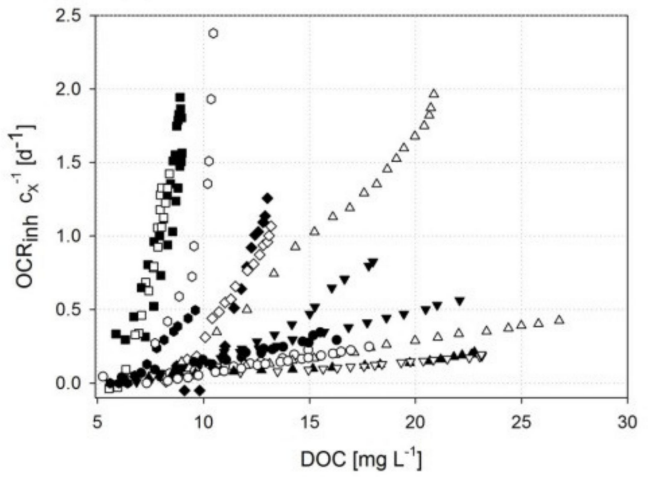

(b)

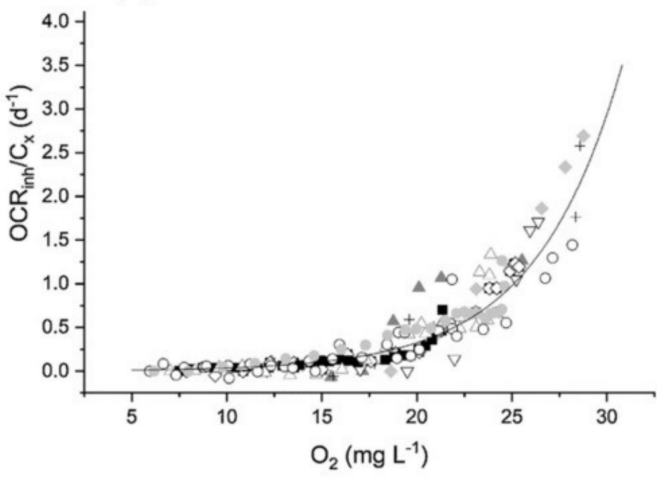

Figure 5. Comparison of the biomass-related inhibiting term $O C R_{\text {inh }}$ depending on the DOC conditions, using (a) the cyanobacterium A. platensis PCC7345 in this study-data are calculated using photorespirometry - and (b) C. protothecoides microalgae in the study by Sforza et al. [36] under varying $c_{x}$ and illumination conditions indicating that the two microorganisms behave differently at high DOCs. The figure shows that a kinetic relationship can be achieved for microalgae (right) under varying $c_{x}$ and $I_{a v}$ conditions (each symbol represents one experimental setting). Such a general kinetic correlation between DOC and $O C R_{\text {inh }}$ is not possible for A. platensis PCC7345.

\subsubsection{Model by Costache et al.}

As a second approach, the oxygen model developed by Costache et al. [35] (Equation (14)), was applied to the photorespirometry data. A typical fitting result of experimental data is presented in Figure 6b).

To compare the two modeling approaches, Table 2 summarizes the model parameters obtained. Both models were able to fit OPR data on the continuous light phase with a high coefficient of determination (Costache: $\mathrm{R}^{2}>0.96$; Sforza: $\mathrm{R}^{2}>0.91$ ). It was found that the oxygen inhibition constant $\mathrm{KO}_{2}$ followed a correlation with the average illumination intensity $I_{a v}$, which can be mathematically described by an exponential correlation $\left(R^{2}>0.83\right.$, Figure 6a):

$$
\mathrm{KO}_{2}=80.489 \mathrm{I}_{a v}{ }^{(-0.476)}
$$

During the experimental data acquisition, high incident $I_{0}$ intensities were revealed to be mitigated by an increasing $c_{x}$ (higher $\mathrm{KO}_{2}$ ) compared to equivalent $I_{a v}$ conditions at low $c_{x}$ (red circle in Figure 6a). This indicated that a buffering effect occurred under higher $c_{x}$ conditions, related to the DOC sensitivity. 
Table 2. Comparison of model parameter resulted by fitting experimental photorespirometry data using the model developed by Costache et al. [35] and Sforza et al. [36].

\begin{tabular}{|c|c|c|c|c|c|c|c|c|}
\hline \multirow[b]{2}{*}{$\begin{array}{c}I_{0} \\
\left(\mu \mathrm{mol} \mathrm{m}{ }^{-2}\right. \\
\left.\mathrm{s}^{-1}\right)\end{array}$} & \multirow[b]{2}{*}{$\begin{array}{c}I_{a v} \\
\left(\mu \mathrm{mol} \mathrm{m}^{-2}\right. \\
\left.\mathrm{s}^{-1}\right)\end{array}$} & \multirow[b]{2}{*}{$\begin{array}{c}\mathcal{c}_{x} \\
\left(\mathrm{~g} \mathrm{~L}^{-1}\right)\end{array}$} & \multicolumn{3}{|c|}{ Costache et al. } & \multicolumn{3}{|c|}{ Sforza et al. } \\
\hline & & & $\begin{array}{l}\mathrm{KO}_{2} \\
\left(\mathrm{mg}_{\mathrm{O} 2} \mathrm{~L}^{-1}\right)\end{array}$ & $\begin{array}{l}z \\
(-)\end{array}$ & $\begin{array}{l}\mathrm{R}^{2} \\
(-)\end{array}$ & $\begin{array}{c}k_{i n h} \\
\left(\mathrm{~d}^{-1}\right)\end{array}$ & $\left(\mathrm{L} \mathrm{mg}^{\xi}{ }^{-1}\right)$ & $\begin{array}{l}\mathrm{R}^{2} \\
{[-]}\end{array}$ \\
\hline \multirow[t]{4}{*}{100} & $16^{\prime}$ & 0.5 & 16.13 & 2.35 & 0.9835 & $1.24 \times 10^{-2}$ & 0.22 & 0.9463 \\
\hline & & & 16.45 & 2.30 & 0.9882 & $1.42 \times 10^{-2}$ & 0.18 & 0.9947 \\
\hline & 13 & 1 & 24.51 & 1.61 & 0.9761 & $2.58 \times 10^{-2}$ & 0.09 & 0.9805 \\
\hline & & & 23.76 & 1.66 & 0.9831 & $2.67 \times 10^{-2}$ & 0.08 & 0.9914 \\
\hline \multirow[t]{6}{*}{150} & 49 & 0.1 & 10.16 & 5.49 & 0.9606 & $1.52 \times 10^{-4}$ & 0.61 & 0.9103 \\
\hline & & & 10.44 & 8.69 & 0.9710 & $1.25 \times 10^{-4}$ & 0.93 & 0.9378 \\
\hline & 24 & 0.5 & 19.14 & 1.62 & 0.9610 & $3.86 \times 10^{-2}$ & 0.13 & 0.9126 \\
\hline & & & 21.40 & 2.07 & 0.9844 & $1.05 \times 10^{-2}$ & 0.18 & 0.9413 \\
\hline & 21 & 0.8 & 22.80 & 1.78 & 0.9847 & $5.24 \times 10^{-2}$ & 0.11 & 0.9442 \\
\hline & & & 27.36 & 1.71 & 0.9870 & $4.49 \times 10^{-2}$ & 0.09 & 0.9466 \\
\hline \multirow[t]{4}{*}{400} & 131 & 0.1 & 8.97 & 5.08 & 0.9886 & $6.47 \times 10^{-3}$ & 0.64 & 0.9896 \\
\hline & & & 8.45 & 6.70 & 0.9990 & $1.16 \times 10^{-3}$ & 0.85 & 0.9971 \\
\hline & 64 & 0.5 & 21.09 & 2.80 & 0.9937 & $3.68 \times 10^{-2}$ & 0.17 & 0.9763 \\
\hline & & & 21.37 & 3.19 & 0.9928 & $3.82 \times 10^{-2}$ & 0.17 & 0.9831 \\
\hline
\end{tabular}

(a)

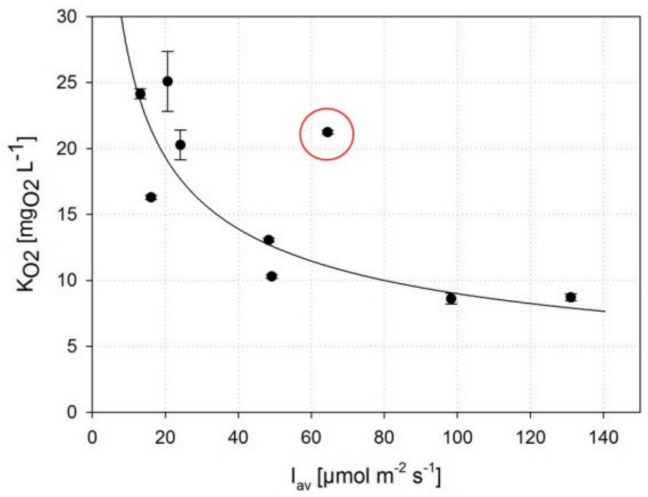

(b)

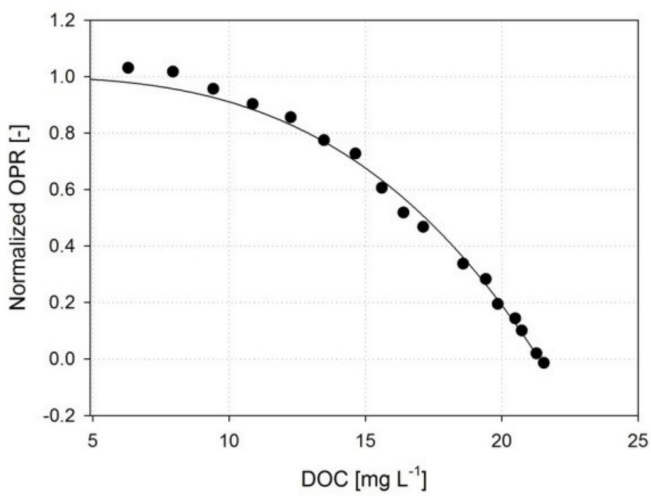

Figure 6. (a) Estimation of the oxygen inhibition constants $\mathrm{KO}_{2}$ by the model proposed by Costache et al. [35] depending on average illumination intensity $I_{a v}$. The red circle corresponds to high $I_{0}$ illumination at high $c_{x}$ yielding (similar $I_{a v}$ conditions such as low $I_{0}$ and low $c_{x}$ ), indicating that high $c_{x}$ conditions may be less sensitive to high DOCs. The solid line marks the course of a power-type function that resulted from fitting the correlation between $K \mathrm{O}_{2}$ and $I_{a v}\left(\mathrm{R}^{2}=0.83\right)$. (b) Example of a typical fitting process according to the model described by Costache et al. [35].

\subsection{Impact of DOCs on Cellular Phycocyanin Content $\left(c_{P C}\right)$}

Besides the impact on growth kinetics, there has been little research so far on how DOCs affect the cellular metabolites of phototrophic microorganisms such as the phycobiliprotein phycocyanin of A. platensis. Here, the exposure phase was introduced in the photorespirometry routine to investigate the temporal impact of high DOCs (approx. $25 \mathrm{mg} \mathrm{L}^{-1}$ ) on the $c_{P C}$ of $A$. platensis PCC7345. Sampling and phycocyanin analytics were performed as shown in Section 2.5.

Figure 7 shows a constant $c_{P C}$ at a $c_{x}$ of $>0.5 \mathrm{~g} \mathrm{~L}^{-1}$ exposed to low $I_{a v}$ of $<49 \mu \mathrm{mol} \mathrm{m} \mathrm{m}^{-2} \mathrm{~s}^{-1}$ during $20 \mathrm{~h}$ of high DOC exposure. A significant reduction in $c_{P C}$ was obtained if either a low $c_{x}$ of $0.1 \mathrm{~g} \mathrm{~L}^{-1}$ was used $\left(0.66 \pm 0.02\right.$ at $\left.I_{a v}=49 \mu \mathrm{E}\right)$ or $I_{a v}$ was $>49 \mu \mathrm{mol} \mathrm{m}^{-2} \mathrm{~s}^{-1}$, indicating that $A$. platensis PCC7345 cultures at low biomass concentrations are more strongly affected by high DOCs. Moreover, high exposure times seemed to exacerbate the harmful effects on $c_{P C}$ under high $I_{a v}$ conditions: after 2 and $4 \mathrm{~h}$ the $c_{P C}$ was reduced by 
less than $20 \%$ followed by a significant further reduction in $c_{P C}$ to $35 \%$ after $20 \mathrm{~h}$ of DOC exposure. Statistical analysis revealed that the phycocyanin content is significantly affected by the exposure duration and the cultivation conditions $(p<0.0001)$.

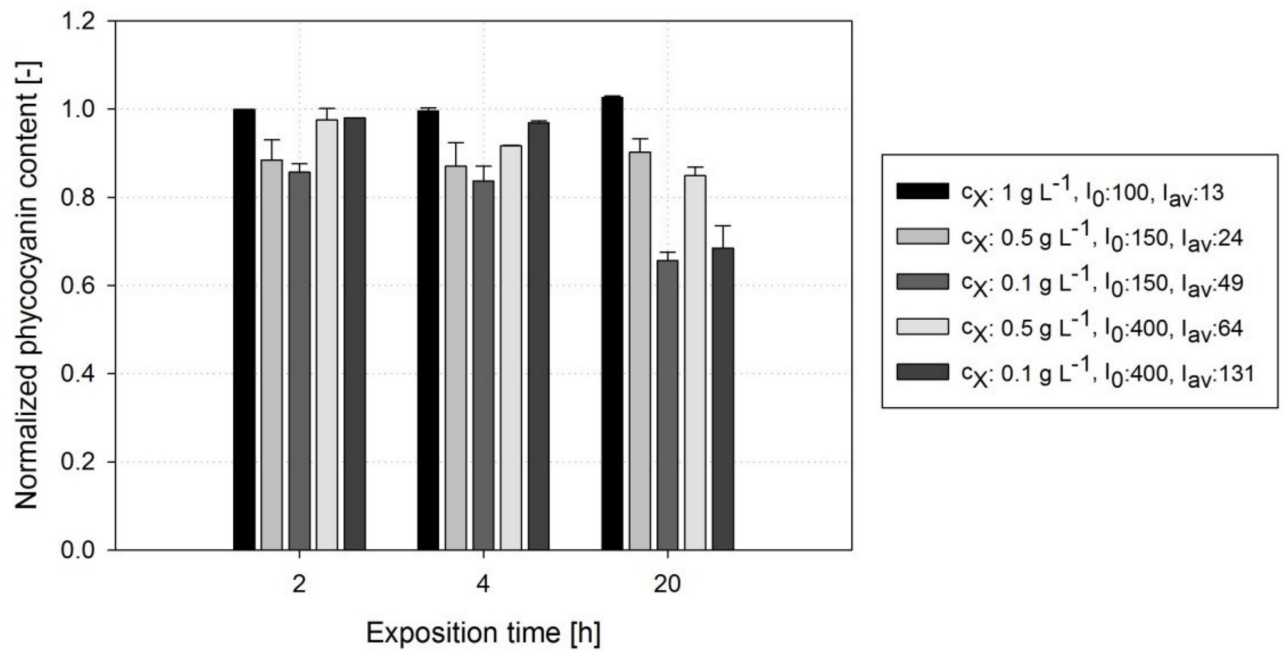

Figure 7. Course of the normalized cellular phycocyanin content $c_{P C}$ during exposure of $A$. platensis PCC7345 cultures to high DOC levels $\left(\approx 25 \mathrm{mg} \mathrm{L}^{-1}\right)$ during the exposure phase of photorespirometry conducted under different light conditions and biomass concentrations.

It was reported that $A$. platensis responds to high illumination intensities by reducing cellular light harvesting pigments to prevent the harmful effects of photoinhibition, among other things [42]. Vonshak et al. [64] detected a decrease in the cellular chlorophyll content of up to $30 \%$ for $A$. platensis exposed to high illumination intensities and oxygen gassing (DOC: $36 \mathrm{mg} \mathrm{L}^{-1}$ ) compared to experiments with air gassing. The authors reported that A. platensis cultures became chlorotic after exposure to both high DOCs and high illumination intensities $\left(I_{0}=350 \mu \mathrm{mol} \mathrm{m} \mathrm{m}^{-2} \mathrm{~s}^{-1}\right)$, indicating that the cells were lastingly damaged by photo-oxidative processes. Marquez et al. [61] observed that after $72 \mathrm{~h}$ of cultivation the phycocyanin content of $A$. platensis was reduced by $85 \%$ when exposed to a DOC of $40 \mathrm{mg} \mathrm{L}^{-1}$ (connected to air saturation) and an $I_{0}$ of $140 \mu \mathrm{mol} \mathrm{m}^{-2} \mathrm{~s}^{-1}$ [61]. In conclusion, in the case of $A$. platensis, the cellular phycocyanin content-one of the major cellular constituents responsible for light harvesting and further industrial valorization-is highly susceptible to high DOC levels, particularly at high illumination intensities and under low $c_{x}$ conditions.

During outdoor cultivation, extreme values of incident illumination intensities (e.g. $1700 \mu \mathrm{mol} \mathrm{m} \mathrm{m}^{-2} \mathrm{~s}^{-1}$ ) and DOCs (e.g., $80 \mathrm{mg} \mathrm{L}^{-1}$ ) can be reached temporarily [24,25]. To tackle the challenges of high illumination intensities, shading devices for PBRs or gas stripping approaches were proposed to prevent cell damage and biomass losses and keep the DOC at a non-critical level. To name an example, Torzillo et al. [24] examined an increase of $50 \%$ in the volumetric biomass productivity of outdoor A. platensis cultivation in tPBRs caused by the application of nitrogen gassing, which lowered the average DOC in the $\mathrm{tPBR}$ from around 60 to $22 \mathrm{mg} \mathrm{L}^{-1}$.

\subsection{Computational Scale-Up Study and Assessment of Biomass Productivity Using Industrial tPBRs with Different Configurations}

The kinetic studies performed on the basis of photorespirometry were used for an in-silico scale-up study for the cultivation of A. platensis PCC7345 on an industrial scale. For this purpose, two different configurations of tPBR were assumed, as described in Section 2.7, having a constant total liquid volume of $5000 \mathrm{~L}$ but with different tube lengths: a serial configuration with an $1800 \mathrm{~m}$ tube and a parallel configuration with a $450 \mathrm{~m}$ tube. 
Table 3 lists the model input parameters including the experimental kinetic parameters which were examined in this study and process parameters derived from literature sources.

Table 3. Input model parameter for in-silico scale-up study on A. platensis PCC7345 in industrial tPBRs with varying configurations.

\begin{tabular}{|c|c|c|}
\hline Parameter & Value & Remarks/Source of Supply \\
\hline$d$ & $6 \mathrm{~cm}$ & $\begin{array}{c}\text { Assumption; tube diameter equal to the light } \\
\text { path length } Z\end{array}$ \\
\hline$L$ & $\begin{array}{l}1800 \mathrm{~m} \\
450 \mathrm{~m}\end{array}$ & Serial configurationParallel configuration \\
\hline$I_{0}$ & variable & \\
\hline$c_{x, 0}$ & variable & \\
\hline$k_{L} a$ & $4 \mathrm{~h}^{-1}$ & Assumption, inspired by [28] \\
\hline$\varepsilon_{g}$ & 0.02 & Assumption, inspired by [28] \\
\hline$c_{\mathrm{O}_{2}, 0}$ & $7.4 \mathrm{mgO} 2^{-1}$ & Solubility concentration of oxygen at $30^{\circ} \mathrm{C}$ \\
\hline$v^{2,0}$ & $0.35 \mathrm{~m} \mathrm{~s}^{-1}$ & Based on [68] \\
\hline$T$ & $30^{\circ} \mathrm{C}$ & Assuming constant temperature conditions \\
\hline$p_{\mathrm{O}_{2}}$ & $0.21 \mathrm{~atm}$ & [39] \\
\hline $\mathrm{H}_{\text {ref }}$ & $\begin{array}{l}1.2 \times 10^{-5} \mathrm{~mol} \mathrm{~m}^{-3} \mathrm{~Pa}^{-1} \\
\text { Kinetic parameters }\end{array}$ & [69] \\
\hline$K_{L}$ & $49.4 \mu \mathrm{mol} \mathrm{m}^{-2} \mathrm{~s}^{-1}$ & This work \\
\hline$Y_{\frac{\mathrm{O}_{2}}{\mathrm{X}}}$ & $1.97 \mathrm{gO} 2_{\mathrm{gx}}{ }^{-1}$ & [25] \\
\hline$\varepsilon$ & $\begin{array}{c}\varepsilon\left[\mathrm{L} \mathrm{cm}^{-1} \mathrm{~g}^{-1}\right] \\
=\left\{\begin{array}{c}-6.83 \cdot c_{x}+5.34, \quad c_{x} \leq 0.355 \mathrm{~g} \mathrm{~L}^{-1} \\
-0.045 \cdot c_{x}+3.014, \quad c_{x}>0.355 \mathrm{~g} \mathrm{~L}^{-1}\end{array}\right.\end{array}$ & This work \\
\hline $\mathrm{KO}_{2}$ & $\mathrm{KO}_{2}=80.489 \cdot I_{a v}(-0.476)$ & This work \\
\hline$z^{2}$ & 1.85 & This work \\
\hline$\mu_{\max }$ & $0.032 \mathrm{~h}^{-1}$ & Experimentally determined \\
\hline
\end{tabular}

In order to investigate how DOC inhibition kinetics influence the process performance, first a comparative study was carried out assuming a continuously operated serial tPBR configuration (a) neglecting DOC inhibition kinetics (Figure 8a) and (b) taking into account DOC inhibition kinetics (Figure 8b).

As can be seen from Figure 8a, the predicted biomass productivity at low incident illumination $I_{0}$ increases with a rising biomass concentration $c_{x, 0}$. In the case of rising $I_{0}$ conditions, the predicted $P_{x}$ increased steadily up to a maximum of approx. $0.8 \mathrm{~g} \mathrm{~L}^{-1} \mathrm{~d}^{-1}$. However, this scenario did not correspond to real process performances, as $P_{x}$ was reported to range between 0.4 and $0.6 \mathrm{~g} \mathrm{~L}^{-1} \mathrm{~d}^{-1}$ for A. platensis cultivations in tPBRs [70-72].

Considering the DOC inhibition kinetics in the model, a different process performance was indicated as the predicted $P_{x}$ was reduced by up to $300 \%$ (approx. $0.25 \mathrm{~g} \mathrm{~L}^{-1} \mathrm{~d}^{-1}$ ) compared to non-limited biomass growth. The maximum predicted $P_{x}$ of the continuous operating serial tPBR was reached under moderate illumination conditions in the range of $200-250 \mu \mathrm{mol} \mathrm{m}^{-2} \mathrm{~s}^{-1}$ with a high initial $c_{x, 0}$. This study found that the DOC inhibition effect is highly dependent on the illumination intensity (illumination-dependent $\mathrm{KO}_{2}$ ) for $A$. platensis PCC7345. Accordingly, the predicted $P_{x}$ decreased significantly in the in-silico study with an increasing incident $I_{0}$ as a high illumination intensity triggers the photoautotrophic growth and oxygen production, leading to a rising DOC inhibition effect. In computational studies, Trentin et al. [34] investigated the growth-inhibiting effects of oxygen on the microalgae $C$. protothecoides in a continuously operated tPBR. This revealed a reduced biomass growth rate in the range of $200-280 \%$ alongside the tube length at high $I_{0}$ intensities (400-1000 $\mu \mathrm{mol} \mathrm{m}^{-2} \mathrm{~s}^{-1}$ ) [34], which is in the same order of magnitude found in this study. 
(a)

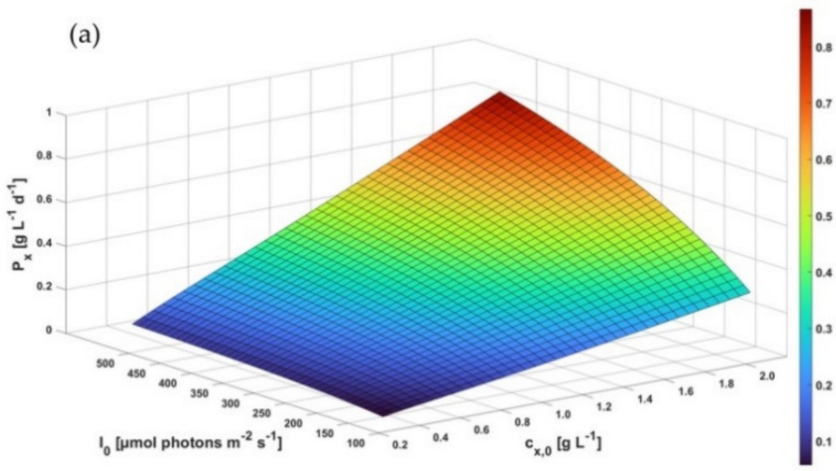

(b)

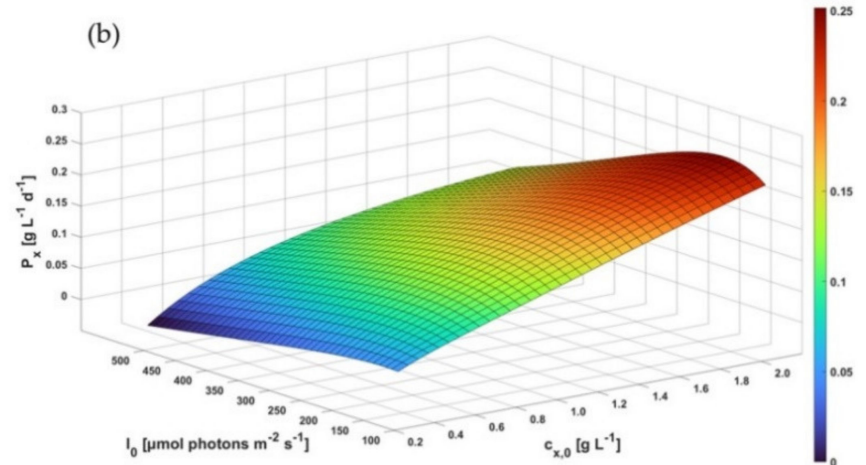

(c)

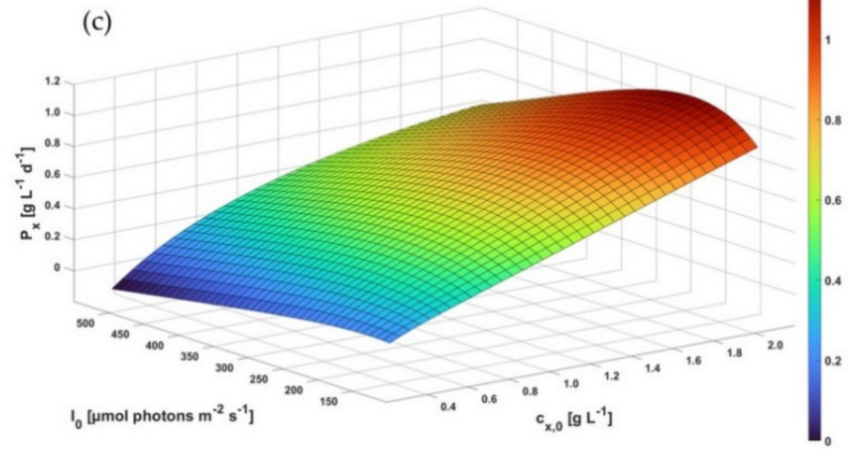

Figure 8. Process modeling of the productivity $P_{x}$ related to cell dry weight concentration $\left(\mathrm{g} \mathrm{L}^{-1} \mathrm{~d}^{-1}\right)$ of $A$. platensis PCC7345 in industrial tPBRs: (a) serial tPBR with a tube length of $1800 \mathrm{~m}$ neglecting DOC inhibition, $\left(\frac{\mathrm{C}_{2}}{\mathrm{KO}_{2}}\right)^{z}=0$, (b) serial $\mathrm{tPBR}$ with a tube length of $1800 \mathrm{~m}$ considering DOC inhibition and (c) parallel tPBR with a tube length of $450 \mathrm{~m}$ considering DOC inhibition.

To reduce the DOC in the liquid phase and mitigate the inhibitory DOC effect, various PBR design options are available such as a reduced tube length and improved degassing units. To quantify the impact of the DOC on $P_{x}$, a parallel tPBR configuration with a maximum tube length of $450 \mathrm{~m}$ was also analyzed (Figure 8c). Assuming the $k_{L} a$ and total liquid volume to be the same, the maximum $P_{x}$ during continuous operation was increased nearly five-fold to approx. $1.16 \mathrm{~g} \mathrm{~L}^{-1} \mathrm{~d}^{-1}\left(I_{0}=190 \mu \mathrm{mol} \mathrm{m}^{-2} \mathrm{~s}^{-1}\right)$, indicating the impact of DOC inhibition kinetics with non-optimal process configurations. Trentin et al. [34] predicted that the tube length for tPBRs would avoid the inhibitory effects of DOCs, ensuring stable $r_{x}$ in C. protothecoides. The authors concluded that to prevent growth from being limited by high DOCs, the tube length should not exceed $200 \mathrm{~m}$, especially for tPBR cultivations with high $c_{x, 0}$ (approx. $1 \mathrm{~g} \mathrm{~L}^{-1}$ ) and high $I_{0}$ (approx. $700-1000 \mu \mathrm{mol} \mathrm{m}^{-2} \mathrm{~s}^{-1}$ ) [34]. Further studies have confirmed that the tube length of tPBRs needs to be limited to prevent high levels of oxygen accumulation $[25,63,73]$ because parts of the tPBRs become non-productive due to oxygen inhibition [27].

The kinetic studies and in-silico scale-up showed that the DOC had a significant impact on the productivity of photoautotrophic bioprocesses, which have to be taken into account in the PBRs' design to ensure they perform optimally. However, the impact is a multidimensional problem, depending on a variety of factors such as the tube diameter, power input, degassing concepts, and the cells' OPR capacity and sensitivity to the DOC. The authors would like to emphasize that the in-silico study was designed by assuming a set of hydrodynamic parameters which may be different for other PBR configurations. 
Supplementary Materials: The following supporting information can be downloaded at: https: / / www.mdpi.com/article/10.3390/chemengineering6010014/s1. Supplementary materials can be downloaded at: Figure S1: Calibration line to quantify dry weight concentration from $\mathrm{OD}_{750}$; Figure S2: Calibration routine for in-vivo phycocyanin quantification from diluted suspended cells; Figure S3: Calibration line for in-vivo phycocyanin quantification from diluted suspended cells by fluorescence spectroscopy; Figure S4: Fluorescence intensity obtained at increasing cell density $\left(\mathrm{OD}_{750}\right)$. An optimum range was detected between $\mathrm{OD}_{750}$ 0.1-0.4. A higher cell density leads to a high re-absorption of fluorescence emission and should be avoided for fluorescence spectroscopy; Table S1: Experimental data of Figure $3\left(\mathrm{OPR}_{\mathrm{D}} / \mathrm{OCR}\right.$ and $\left.\mathrm{OPR}_{\mathrm{L}} / \mathrm{OPR}\right)$ and Figure 6a $(\mathrm{KO} 2)$; Table S1: Experimental data of Figure 7.

Author Contributions: Conceptualization of the manuscript, S.F. and F.K.; methodology, S.F.; software, S.F.; validation, S.F., F.K.; resources, T.W. and J.S.; writing-original draft preparation, S.F. and F.K.; writing - review and editing, T.W. and J.S.; All authors have read and agreed to the published version of the manuscript.

Funding: We thank the German Research Foundation (DFG; grant no. KR 5050/2-1) for supporting this research.

Institutional Review Board Statement: Not applicable.

Informed Consent Statement: Not applicable.

Data Availability Statement: The raw data are available on request.

Conflicts of Interest: The authors declare no conflict of interest.

\section{Abbreviations}

\section{Symbol Description}

$H_{\mathrm{O}_{2}} \quad$ Henry's constant (Henry's law)

$H_{\text {ref }} \quad$ reference Henry's constant (Henry's law)

I light intensity

$I_{0} \quad$ incident light intensity

$I_{a v} \quad$ average light intensity

$I_{f, \max }$

$\mathrm{K}_{\mathrm{CO}_{2}}$

$K_{L}$

$K_{M, O 2}$

$\mathrm{KO}_{2}$

$K_{P R}$

$L$

OCR

$O C R_{\text {inh }}$

$O C R_{\text {resp }}$

$O P R$

$O P R_{\max }$

$O P R_{\text {net }}$

$O P R_{p h}$

$O D_{750}$

$T_{\text {ref }}$

$Y_{\frac{\mathrm{O}_{2}}{x}}$

$Z^{\frac{\mathrm{O}_{2}}{x}}$

$c_{\mathrm{CO}_{2}}$

$\mathrm{c}_{\mathrm{O}_{2}}$

$\mathrm{c}_{\mathrm{O}_{2}, 0}$ maximum fluorescence intensity

half-saturation constant for $\mathrm{CO}_{2}$ (model by Sforza)

light half-saturation constant

oxygen half-saturation constant for respiration

(model by Sforza)

oxygen inhibition constant (model by Costache)

photorespiration constant (model by Sforza)

tube length of the solar unit

oxygen consumption rate

oxygen inhibition rate (model by Sforza)

oxygen respiration rate (model by Sforza)

oxygen production rate

biomass-related maximum rate of photosynthesis

net oxygen production rate (Sforza model)

photosynthetic oxygen production (Sforza model)

optical density at a light wavelength of $750 \mathrm{~nm}$

reference temperature (Henry's law)

yield of oxygen produced per biomass

light path length

concentration of dissolved $\mathrm{CO}_{2}$

oxygen concentration in the liquid phase

oxygen concentration at the inlet of the solar unit

Unit
$\mathrm{mol} \mathrm{m}^{-3} \mathrm{~Pa}^{-1}$
$\mathrm{~mol} \mathrm{~m}^{-3} \mathrm{~Pa}^{-1}$
$\mu \mathrm{mol}$ photons $\mathrm{m}^{-2} \mathrm{~s}^{-1}$
$\mu \mathrm{mol}$ photons $\mathrm{m}^{-2} \mathrm{~s}^{-1}$
$\mu \mathrm{mol}$ photons $\mathrm{m}^{-2} \mathrm{~s}^{-1}$
$\mathrm{~kg}_{\mathrm{C}} \mathrm{m}^{-3}$
$\mu \mathrm{mol}$ photons $\mathrm{m}^{-2} \mathrm{~s}^{-1}$
$\mathrm{~kg}_{\mathrm{O} 2} \mathrm{~m}^{-3}$
$\mathrm{~kg} \mathrm{~m}^{-3}$
$\mathrm{~kg}_{\mathrm{O} 2} \mathrm{~m}^{-3}$
$\mathrm{~m}$
$\mathrm{kgO}^{-3} \mathrm{~m}^{-3} \mathrm{~s}^{-1}$
$\mathrm{~kg}_{\mathrm{O} 2} \mathrm{~m}^{-3} \mathrm{~s}^{-1}$
$\mathrm{~kg}_{\mathrm{O} 2} \mathrm{~kg}^{-1} \mathrm{~s}^{-1}$
$\mathrm{~kg}_{\mathrm{O} 2} \mathrm{~m}^{-3} \mathrm{~s}^{-1}$
$\mathrm{~kg}_{\mathrm{O} 2} \mathrm{~m}^{-3} \mathrm{~s}^{-1}$
$\mathrm{~K}$
$\mathrm{~kg}_{\mathrm{O} 22 \mathrm{~kg}^{-1}}$
$\mathrm{~m}^{\mathrm{kg}_{\mathrm{C}} \mathrm{m}^{-3}}$
$\mathrm{~kg}_{\mathrm{O} 2} \mathrm{~m}^{-3}$
$\mathrm{~kg}_{\mathrm{O} 2} \mathrm{~m}^{-3}$

Unit

$\mathrm{mol} \mathrm{m}^{-3} \mathrm{~Pa}^{-1}$

$\mu \mathrm{mol}$ photons $\mathrm{m}^{-2} \mathrm{~s}^{-1}$

$\mu \mathrm{mol}$ photons $\mathrm{m}^{-2} \mathrm{~s}^{-1}$

$\mathrm{kg}_{\mathrm{C}} \mathrm{m}^{-3}$

$\mathrm{kg}_{\mathrm{O} 2} \mathrm{~m}^{-3}$

$\mathrm{kg} \mathrm{m}^{-3}$

$\mathrm{kg}_{2} \mathrm{~m}^{-3}$

$\mathrm{kg}_{\mathrm{O} 2} \mathrm{~m}^{-3} \mathrm{~s}^{-1}$

$\mathrm{kg}_{\mathrm{O} 2} \mathrm{~kg}_{\mathrm{x}}{ }^{-1} \mathrm{~s}^{-1}$

$\mathrm{kg}_{2} \mathrm{~m}^{-3} \mathrm{~s}^{-1}$

$\mathrm{kgO}_{2} \mathrm{~m}^{-3} \mathrm{~s}^{-1}$

K

$\mathrm{m}$

$\mathrm{kg}_{\mathrm{O} 2} \mathrm{~m}^{-3}$

$\mathrm{kg}_{2} \mathrm{~m}^{-3}$ 


$\begin{array}{lll}c_{\mathrm{O}_{2}, \text { out }} & \text { oxygen concentration at the outlet of the solar unit } & \mathrm{kgO} \mathrm{m}^{-3} \\ c_{\mathrm{O}_{2}}^{*} & \text { saturation concentration of oxygen in the liquid phase } & \mathrm{kgO}^{-3} \mathrm{~m}^{-3} \\ c_{P C} & \text { phycocyanin content (biomass-related) } & \mathrm{kg}_{\mathrm{PC} ~ \mathrm{~kg}_{x}-1} \\ c_{x} & \text { biomass concentration } & \mathrm{kg} \mathrm{m}^{-3} \\ c_{x, 0} & \text { biomass concentration at the inlet of the solar unit } & \mathrm{kg}^{-3} \\ c_{x, \text { out }} & \text { biomass concentration at the outlet of the solar unit } & \mathrm{kg}^{-3} \mathrm{~m}^{-3} \\ k_{\mathrm{L}} a & \text { oxygen mass transfer coefficient } & \mathrm{s}^{-1} \\ l & \text { tube length of the solar unit (running coordinate) } & \mathrm{m} \\ p_{\mathrm{O}_{2}} & \text { oxygen partial pressure } & \mathrm{Pa} \\ r_{\mathrm{O}_{2}} & \text { oxygen production rate } & \mathrm{kg}_{\mathrm{O} 2} \mathrm{~m}^{-3} \mathrm{~s}^{-1} \\ r_{x} & \text { biomass growth rate } & \mathrm{kg}_{\mathrm{x}} \mathrm{m}^{-3} \mathrm{~s}^{-1} \\ v & \text { flow velocity } & \mathrm{m} \mathrm{s}^{-1} \\ z & \text { form factor (model by Costache) } & \\ \varepsilon & \text { cell-specific light attenuation coefficient } & \mathrm{m}^{2} \mathrm{~kg}^{-1} \\ \varepsilon_{g} & \text { fractional gas hold-up } & \\ \mu & \text { specific growth rate } & \mathrm{s}^{-1} \\ \mu_{\mathrm{O}_{2}} & \text { maximum specific oxygen rate (model by Sforza) } & \mathrm{s}^{-1} \\ \mu_{\text {max }} & \text { maximum growth rate } & \mathrm{s}^{-1} \\ \varsigma & \text { oxygen inhibition exponent (model by Sforza) } & \mathrm{m}^{3} \mathrm{~kg}^{-1} \\ \tau & \text { residence time } & \mathrm{s}\end{array}$

\section{References}

1. Borowitzka, M.A.; Gershwin, M.E.; Belay, A. (Eds.) Spirulina in Human nutrition and Health; CRC Press: Boca Raton, FL, USA, 2008; 312p.

2. $\quad$ Lupatini, A.L.; Colla, L.M.; Canan, C.; Colla, E. Potential application of microalga Spirulina platensis as a protein source. J. Sci. Food Agric. 2017, 97, 724-732. [CrossRef] [PubMed]

3. Mahmoud, M.M.A.; El-Lamie, M.M.M.; Kilany, O.E.; Dessouki, A.A. Spirulina (Arthrospira platensis) supplementation improves growth performance, feed utilization, immune response, and relieves oxidative stress in Nile tilapia (Oreochromis niloticus) challenged with Pseudomonas fluorescens. Fish Shellfish. Immunol. 2018, 72, 291-300. [CrossRef] [PubMed]

4. Rosas, V.T.; Poersch, L.H.; Romano, L.A.; Tesser, M.B. Feasibility of the use of Spirulina in aquaculture diets. Rev. Aquac. 2019, 11, 1367-1378. [CrossRef]

5. Eriksen, N.T. Production of phycocyanin-a pigment with applications in biology, biotechnology, foods and medicine. Appl Microbiol. Biotechnol. 2008, 80, 1-14. [CrossRef] [PubMed]

6. Ramamoorthy, A.; Premakumari, S. Effect of supplementation of Spirulina on hypercholesterolemic patients. Food Sci. Technol. 1996, 33, 124-127.

7. Samuels, R.; Mani, U.V.; Iyer, U.M.; Nayak, U.S. Hypocholesterolemic Effect of Spirulina in Patients with Hyperlipidemic Nephrotic Syndrome. J. Med. Food 2002, 5, 91-96. [CrossRef] [PubMed]

8. Czerwonka, A.; Kaławaj, K.; Sławińska-Brych, A.; Lemieszek, M.K.; Bartnik, M.; Wojtanowski, K.; Zdzisińska, B.; Rzeski, W. Anticancer effect of the water extract of a commercial Spirulina (Arthrospira platensis) product on the human lung cancer A549 cell line. Biomed. Pharmacother. 2018, 106, 292-302. [CrossRef]

9. Maryati, M.; Saifudin, A.; Wahyuni, S.; Rahmawati, J.; Arrum, A.; Priyunita, O.; Aulia, A.; Putra, F.; As'Hari, Y.; Rasyidah, U.; et al. Cytotoxic effect of Spirulina platensis extract and Ulva compressa Linn. on cancer cell lines. Food Res. 2020, 4, 1018-1023. [CrossRef]

10. Joseph, J.; Thankamani, K.; Ajay, A.; Das, V.R.A.; Raj, V.S. The Use of Pseudotyped Coronaviruses for the Screening of Entry Inhibitors: Green Tea Extract Inhibits the Entry of SARS-CoV-1, MERS-CoV, and SARS-CoV-2 by Blocking Receptor-Spike Interaction. Curr. Pharm. Biotechno. 2021, 22, 1-12. [CrossRef]

11. Abu-Taweel, G.M.; Mohsen, G.A.-M.; Antonisamy, P.; Arokiyaraj, S.; Kim, H.-J.; Kim, S.-J.; Park, K.H.; Kim, Y.O. Spirulina consumption effectively reduces anti-inflammatory and pain related infectious diseases. J. Infect. Public Health 2019, 12, 777-782. [CrossRef]

12. Jensen, G.S.; Attridge, V.L.; Beaman, J.L.; Guthrie, J.; Ehmann, A.; Benson, K.F. Antioxidant and Anti-Inflammatory Properties of an Aqueous Cyanophyta Extract Derived from Arthrospira Platensis: Contribution to Bioactivities by the Non-Phycocyanin Aqueous Fraction. J. Med. Food 2015, 18, 535-541. [CrossRef] [PubMed]

13. Taufikurahman, T.; Ilhamsyah, D.P.A.; Rosanti, S.; Ardiansyah, M.A. Preliminary Design of Phycocyanin Production from Spirulina platensis Using Anaerobically Digested Dairy Manure Wastewater. In IOP Conference Series: Earth and Environmental Science; IOP Publishing: Bristol, UK, 2020; p. 012007.

14. Jassby, A. Spirulina: A model for microalgae as human food. In Algae and Human Affairs; Lembi, C.A., Waaland, J.R., Eds.; Cambridge University Press: Cambridge, UK, 1988; pp. 149-179. 
15. Dawczynski, J.; Jentsch, S.; Schweitzer, D.; Hammer, M.; Lang, G.E.; Strobel, J. Long term effects of lutein, zeaxanthin and omega-3-LCPUFAs supplementation on optical density of macular pigment in AMD patients: The LUTEGA study. Graefes Arch. Clin. Exp. Ophthalmol. 2013, 251, 2711-2723. [CrossRef] [PubMed]

16. Seddon, J.M.; Ajani, U.A.; Sperduto, R.D.; Hiller, R.; Blair, N.; Burton, T.C.; Farber, M.D.; Gragoudas, E.S.; Haller, J.; Miller, D.T.; et al. Dietary carotenoids, vitamins A, C, and E, and advanced age-related macular degeneration. Eye Disease Case-Control Study Group. JAMA 1994, 272, 1413-1420. [CrossRef]

17. Cohen, Z. The chemicals of Spirulina. In Spirulina Platensis (Arthrospira): Physiology, Cell-Biology and Biotechnology; Vonshak, A., Ed.; CRC Press: London, UK, 1997; pp. 175-204.

18. Fan, Y.Y.; Ramos, K.S.; Chapkin, R.S. Dietary gamma-linolenic acid suppresses aortic smooth muscle cell proliferation and modifies atherosclerotic lesions in apolipoprotein E knockout mice. J. Nutr. 2001, 131, 1675-1681. [CrossRef]

19. Van Hoorn, R.; Kapoor, R.; Kamphuis, J. A short review on sources and health benefits of GLA, The GOOD omega-6. Oléagineux Corps Gras Lipides 2008, 15, 262-264. [CrossRef]

20. Posten, C. Design principles of photo-bioreactors for cultivation of microalgae. Eng. Life Sci. 2009, 9, 165-177. [CrossRef]

21. Carvalho, A.P.; Meireles, L.A.; Malcata, F.X. Microalgal Reactors: A Review of Enclosed System Designs and Performances. Biotechnol. Prog. 2006, 22, 1490-1506. [CrossRef] [PubMed]

22. Lee, Y.-K. Microalgal mass culture systems and methods: Their limitation and potential. J. Appl. Phycol. 2001, 13, 307-315. [CrossRef]

23. Weissman, J.C.; Goebel, R.P.; Benemann, J.R. Photobioreactor design: Mixing, carbon utilization, and oxygen accumulation. Biotechnol. Bioeng. 1988, 31, 336-344. [CrossRef]

24. Torzillo, G.; Bernardini, P.; Masojídek, J. On-line monitoring of chlorophyll fluorescence to assess the extent of photoinhibition of photosynthesis induced by high oxygen concentration and low temperature and its effect on the productivity of outdoor cultures of Spirulina platensis (Cyanobacteria). J. Phycol. 1998, 34, 504-510. [CrossRef]

25. Torzillo, G.; Chini Zittelli, G. Tubular Photobioreactors. In Algal Biorefineries; Prokop, A., Bajpai, R.K., Zappi, M.E., Eds.; Springer International Publishing: Cham, Switzerland, 2015; pp. 187-212.

26. Kazbar, A.; Cogne, G.; Urbain, B.; Marec, H.; Le-Gouic, B.; Tallec, J.; Takache, H.; Ismail, A.; Pruvost, J. Effect of dissolved oxygen concentration on microalgal culture in photobioreactors. Algal Res. 2019, 39, 101432. [CrossRef]

27. Rubio, F.C.; Camacho, F.G.; Grima, E.M. Prediction of dissolved oxygen and carbon dioxide concentration profiles in tubular photobioreactors for microalgal culture. Biotechnol. Bioeng. 1999, 62, 16. [CrossRef]

28. Babcock, R.W.; Malda, J.; Radway, J.C. Hydrodynamics and mass transfer in a tubular airlift photobioreactor. J. Appl. Phycol. 2002, 14, 169-184. [CrossRef]

29. Chai, X.; Zhao, X. Enhanced removal of carbon dioxide and alleviation of dissolved oxygen accumulation in photobioreactor with bubble tank. Bioresour. Technol. 2012, 116, 360-365. [CrossRef]

30. Ojanen, S.; Tyystjärvi, E.; Holmberg, H.; Ahtila, P. Porous membrane as a means of gas and nutrient exchange in a tubular photobioreactor. J. Appl. Phycol. 2015, 27, 1169-1175. [CrossRef]

31. Ferreira, B.S.; Fernandes, H.L.; Reis, A.; Mateus, M. Microporous hollow fibres for carbon dioxide absorption: Mass transfer model fitting and the supplying of carbon dioxide to microalgal cultures. J. Chem. Technol. Biotechnol. 1998, 71, 61-70. [CrossRef]

32. Pires, J.C.M.; Alvim-Ferraz, M.C.M.; Martins, F.G. Photobioreactor design for microalgae production through computational fluid dynamics: A review. Renew. Sustain. Energy Rev. 2017, 79, 248-254. [CrossRef]

33. Massart, A.; Mirisola, A.; Lupant, D.; Thomas, D.; Hantson, A.-L. Experimental characterization and numerical simulation of the hydrodynamics in an airlift photobioreactor for microalgae cultures. Algal Res. 2014, 6, 210-217. [CrossRef]

34. Trentin, G.; Barbera, E.; Bertucco, A.; Sforza, E. Role of oxygen in tubular photobioreactors: Model-Based design and operating conditions to minimize productivity losses. Chem. Eng. Processing-Process 2020, 157, 108151. [CrossRef]

35. Costache, T.A.; Acién Fernández, F.G.; Morales, M.M.; Fernández-Sevilla, J.M.; Stamatin, I.; Molina, E. Comprehensive model of microalgae photosynthesis rate as a function of culture conditions in photobioreactors. Appl. Microbiol. Biotechnol. 2013, 97, 7627-7637. [CrossRef]

36. Sforza, E.; Pastore, M.; Franke, S.M.; Barbera, E. Modeling the oxygen inhibition in microalgae: An experimental approach based on photorespirometry. New Biotechnol. 2020, 59, 26-32. [CrossRef] [PubMed]

37. Krujatz, F.; Illing, R.; Krautwer, T.; Liao, J.; Helbig, K.; Goy, K.; Opitz, J.; Cuniberti, G.; Bley, T.; Weber, J. Light-field-characterization in a continuous hydrogen-producing photobioreactor by optical simulation and computational fluid dynamics. Biotechnol. Bioeng. 2015, 112, 2439-2449. [CrossRef] [PubMed]

38. Rossi, S.; Bellucci, M.; Marazzi, F.; Mezzanotte, V.; Ficara, E. Activity assessment of microalgal-bacterial consortia based on respirometric tests. Water Sci. Technol. 2018, 78, 207-215. [CrossRef] [PubMed]

39. Sforza, E.; Pastore, M.; Barbera, E.; Bertucco, A. Respirometry as a tool to quantify kinetic parameters of microalgal mixotrophic growth. Bioprocess Biosyst. Eng. 2019, 42, 839-851. [CrossRef]

40. Takors, R.; Weuster-Botz, D. Prozessmodelle. In Bioprozesstechnik, 4th ed.; Chmiel, H., Takors, R., Weuster-Botz, D., Eds.; Springer Spektrum: Berlin/Heidelberg, Germany, 2018; pp. 71-105.

41. ASCE. Measurement of Oxygen Transfer in Clean Water, 2nd ed.; American Society of Civil Engineers: New York, NY, USA, 1993.

42. Vonshak, A. Spirulina: Growth, Physiology and Biochemistry. In Spirulina Platensis Arthrospira: Physiology, Cell-Biology and Biotechnology; Vonshak, A., Ed.; CRC Press: London, UK, 1997; pp. 43-66. 
43. Bennett, A.; Bogorad, L. Complementary chromatic adaptation in a filamentous blue-green alga. J. Cell Biol. 1973, 58, 419-435. [CrossRef]

44. Vanrolleghem, P.; Borchardt, D.; Henze, M.; Rauch, W.; Reichert, P.; Shanahan, P.; Somlyódy, L. River Water Quality Model no. 1 (RWQM1): III. Biochemical submodel selection. Water Sci. Technol. 2001, 43, 31-40. [CrossRef]

45. Schuurmans, R.M.; van Alphen, P.; Schuurmans, J.M.; Matthijs, H.C.P.; Hellingwerf, K.J. Comparison of the photosynthetic yield of cyanobacteria and green algae: Different methods give different answers. PLoS ONE 2015, 10, e0139061. [CrossRef]

46. Grima, E.M.; Fernandez, F.G.A.; Camacho, F.G.; Chisti, Y. Photobioreactors: Light regime, mass transfer, and scaleup. J. Biotechnol. 1999, 70, 231-247. [CrossRef]

47. Geider, R.J.; Osborne, B.A. Respiration and microalgal growth: A review of the quantitative relationship between dark respiration and growth. New Phytol. 1989, 112, 327-341. [CrossRef]

48. Laws, E.A.; Bannister, T.T. Nutrient- and light-limited growth of Thalassiosira fluviatilis in continuous culture, with implications for phytoplankton growth in the ocean1. Limnol. Oceanogr. 1980, 25, 457-473. [CrossRef]

49. Laws, E.; Caperon, J. Carbon and nitrogen metabolism by Monochrysis lutheri: Measurement of growth-rate-dependent respiration rates. Mar. Biol. 1976, 36, 85-97. [CrossRef]

50. Ogbonna, J.; Tanaka, H. Light requirement and photosynthetic cell cultivation-Development of processes for efficient light utilization in photobioreactors. J. Appl. Phycol. 2000, 12, 207-218. [CrossRef]

51. Béchet, Q.; Shilton, A.; Guieysse, B. Modeling the effects of light and temperature on algae growth: State of the art and critical assessment for productivity prediction during outdoor cultivation. Biotechnol. Adv. 2013, 31, 1648-1663. [CrossRef] [PubMed]

52. Pruvost, J.; Cornet, J.F.; Goetz, V.; Legrand, J. Theoretical investigation of biomass productivities achievable in solar rectangular photobioreactors for the cyanobacterium Arthrospira platensis. Biotechnol. Prog. 2012, 28, 699-714. [CrossRef] [PubMed]

53. Phélippé, M.; Gonçalves, O.; Thouand, G.; Cogne, G.; Laroche, C. Characterization of the polysaccharides chemical diversity of the cyanobacteria Arthrospira platensis. Algal Res. 2019, 38, 101426. [CrossRef]

54. Krause, G. The Role of Oxygen in Photoinhibition of Photosynthesis. In Causes of Photooxidative Stress and Amelioration of Defense Systems in Plants, 2nd ed.; Foyer, C.H., Mullineaux, C.W., Eds.; CRC Press: New York, NY, USA, 1994; pp. $43-76$.

55. Latifi, A.; Ruiz, M.; Zhang, C.-C. Oxidative stress in cyanobacteria. FEMS Microbiol. Rev. 2009, 33, 258-278. [CrossRef]

56. Badger, M.R.; von Caemmerer, S.; Ruuska, S.; Nakano, H. Electron flow to oxygen in higher plants and algae: Rates and control of direct photoreduction (Mehler reaction) and rubisco oxygenase. Phil. Trans. R. Soc. Lond. B 2000, 355, 1433-1446. [CrossRef]

57. Hsieh, P.; Pedersen, J. Reactive oxygen species in cyanobacteria. In Cyanobacteria: Ecological Importance, Biotechnological Uses and Risk Management, 1st ed.; Davison, D., Ed.; Nova Science Publishers: New York, NY, USA, 2014; pp. 1-41.

58. Allahverdiyeva, Y.; Isojärvi, J.; Zhang, P.; Aro, E.-M. Cyanobacterial Oxygenic Photosynthesis is Protected by Flavodiiron Proteins. Life 2015, 5, 716-743. [CrossRef]

59. Raven, J.A.; Beardall, J. Respiration in aquatic photolithotrophs. In Respiration in Aquatic Ecosystem; Del Giorgio, P.E., Williams, P.J.L.B., Eds.; Oxford University Press: Oxford, UK; New York, NY, USA, 2005; pp. 36-46.

60. Sousa, C.; Compadre, A.; Vermuë, M.H.; Wijffels, R.H. Effect of oxygen at low and high light intensities on the growth of Neochloris oleoabundans. Algal Res. 2013, 2, 122-126. [CrossRef]

61. Marquez, F.J.; Sasaki, K.; Nishio, N.; Nagai, S. Inhibitory effect of oxygen accumulation on the growth of Spirulina platensis. Biotechnol. Lett. 1995, 17, 225-228. [CrossRef]

62. Torzillo, G.; Giovannetti, L.; Bocci, F.; Materassi, R. Effect of oxygen concentration on the protein content of Spirulina biomass. Biotechnol. Bioeng. 1984, 26, 1134-1135. [CrossRef] [PubMed]

63. Torzillo, G. Tubular bioreactors. In Spirulina platensis (Arthrospira): Physiology, Cell-Biology and Biotechnology, 1st ed.; CRC Press: London, UK, 1997; pp. 101-115.

64. Vonshak, A.; Torzillo, G.; Accolla, P.; Tomaselli, L. Light and oxygen stress in Spirulina platensis (cyanobacteria) grown outdoors in tubular reactors. Physiol. Plant 1996, 97, 175-179. [CrossRef]

65. Sousa, C.; de Winter, L.; Janssen, M.; Vermuë, M.; Wijffels, R.H. Growth of the microalgae Neochloris oleoabundans at high partial oxygen pressures and sub-saturating light intensity. Bioresour. Technol. 2012, 104, 565-570. [CrossRef] [PubMed]

66. Raso, S.; van Genugten, B.; Vermuë, M.; Wijffels, R.H. Effect of oxygen concentration on the growth of Nannochloropsis sp. at low light intensity. J. Appl. Phycol. 2012, 24, 863-871. [CrossRef] [PubMed]

67. Beaumont, J.A.G. Impact of Oxygen on Cyanobacterium Arthrospira sp. PCC 8005, Master End Project; EHU-UPV: Leioa, Spain, 2015.

68. Molina, E.; Fernández, J.; Acién, F.G.; Chisti, Y. Tubular photobioreactor design for algal cultures. J. Biotechnol. 2001, 92, 113-131. [CrossRef]

69. Warneck, P.; Williams, J. Aqueous Phase Chemistry. In The Atmospheric Chemist's Companion: Numerical Data for Use in the Atmospheric Sciences, 1st ed.; Warneck, P., Williams, J., Eds.; Springer: Dodrecht, The Netherlands, 2012; pp. $271-314$.

70. Converti, A.; Lodi, A.; Del Borghi, A.; Solisio, C. Cultivation of Spirulina platensis in a combined airlift-tubular reactor system. Biochem. Eng. J. 2006, 32, 13-18. [CrossRef]

71. Torzillo, G.; Sacchi, A.; Materassi, R.; Richmond, A. Effect of temperature on yield and night biomass loss in Spirulina platensis grown outdoors in tubular photobioreactors. J. Appl. Phycol. 1991, 3, 103-109. [CrossRef] 
72. Travieso, L.; Hall, D.O.; Rao, K.K.; Benítez, F.; Sánchez, E.; Borja, R. A helical tubular photobioreactor producing Spirulina in a semicontinuous mode. Int. Biodeterior. Biodegrad. 2001, 47, 151-155. [CrossRef]

73. Acién Fernández, F.G.; Fernández Sevilla, J.M.; Sánchez Pérez, J.A.; Grima, E.M.; Chisti, Y. Airlift-driven external-loop tubular photobioreactors for outdoor production of microalgae: Assessment of design and performance. Chem. Eng. Sci. 2001, 56, 2721-2732. [CrossRef] 